This report was funded by the Bonneville Power Administration (BPA), U.S. Department of Energy, as part of BPA's program to protect, mitigate, and enhance fish and wildlife affected by the development and operation of hydroelectric facilities on the Columbia River and its tributaries. The views in this report are the author's and do not necessarily represent the views of BPA.

For additional copies of this report, write to:

Bonneville Power Administration

Public Information Center - CKPS-1

P.O. Box 3621

Portland, OR 97208

Please include title, author, and DOE/BP number from the back cover in the request. 


\title{
BULL TROUT LIFE HISTORY, GENETICS, HABITAT NEEDS, AND LIMITING FACTORS IN CENTRAL AND NORTHEAST OREGON
}

\section{ANNUAL REPORT}

\author{
Prepared by: \\ Blane L. Bellerud \\ Stephanie Gunckel \\ Alan R. Hemmingsen \\ David V. Buchanan \\ Oregon Department of Fish and Wildlife \\ Portland, OR \\ and \\ Philip J. Howell \\ U.S. Forest Service \\ North Fork John Day Ranger District \\ Ukiah, OR
}

Prepared for:

U. S. Department of Energy

Bonneville Power Administration

Environment, Fish and Wildlife

P.O. Box 3621

Portland, OR 97208-362 1

Project Number 95-54

Contract Number 94BI34342

OCTOBER 1997 


\section{ACKNOWLEDGMENTS}

This study is part of a multi-year research project studying aspects of bull trout life history, ecology and genetics primarily funded by a grant form the Bonniville Power Administration. We also receive cooperation from the Oregon Department of Fish and Wildlife, U.S. Forest Service, Portland General Electric, the Confederated Tribes of Warm Springs and the Confederated Tribes of the Umatilla Indian Reservation.

We wish to thank Mary Lou Keefe and Brian Jonassen of the ODFW

Grande Ronde chinook life history study and Peter Lofy and Mike McLean of the Confederated Tribes of the Umatilla for providing bull trout catch data from their trapping operations. We also received substantial support and information from the Northeast Regional Office and the LaGrande, John Day, Wallowa, Umatilla District Offices of the Oregon Department of Fish and Wildlife. We also wish to acknowledge the efforts of Jason Shappart, Steven Starcevich, Sharmane Steigerwald, Lisa Summerfeld and Sarah Chamberlin. They conducted most of the sampling required to gather the data presented in this report. 


\section{Abstract}

This report covers the activities of our project in 1996. We present results and analysis in five areas. Work plan objectives addressed included 1.2,1.3,2.1,3.1,5.1,5.2,5.3,5.4,5.5,6.1,6.2,6.3 and 6.4 (Hemmingsen et al. 1995)

Analysis of nuclear satellite DNA in combination with previous genetic studies indicated that bull trout in Oregon belong to three major lineages; coastal (those west of the mouth of the John Day River), Klamath (those in the Klamath basin), and inland (those east of the mouth of the John Day River). It was found that there was little genetic variability within populations but substantial variation was found between populations.

Distribution surveys of sympatric populations of brook trout and bull trout revealed 3 distinct zones of distribution within streams, zones with only bull trout or brook trout and a zone with both species. Most streams surveyed had zones with only brook trout and zones with only bull trout separated by a relatively short reach containing both species. However, some streams only contained a zone with only bull trout and a zone with both species.

Multiple spawning surveys were conducted on three streams: Mill Creek (Walla Walla Basin) which supports a population of fluvial bull trout. The Little Minam River (Grande Ronde Drainage) which has a population of resident bull trout and Silver Creek (Powder Drainage) which also has a resident population. Spawning in all three populations peaked in the last week of September and first week of October. It was also found that resident bull trout build significantly smaller redds than fluvial populations and that substrate type can significantly effect the ability to detect redds and thus the dependability of redd counts.

Historic trap catches of downstream migrating juvenile bull trout in the Grande Ronde Basin were compiled and analyzed. It was found that there are two runs; one peaking in April and May composed mainly of 2-3 year old fish and one peaking in September and October with a large component of 3-4 year old fish. The runs are separated by a period of low migration in July. It appears that the spring run is associated with high spring flows in the Grande Ronde River and the start of the fall run is associated with cooling of the Grande Ronde River in the fall. Length frequencies of emigrating juvenile bull from Lookinglass Creek from 1965-71 and from 1993-96 were compared. It was found that emigrating juveniles from 196571 were significantly larger $(p=0.05)$ than juveniles from 1993-96.

Preliminary studies were conducted in Big Creek (Malheur basin) and the Upper North Powder River (Powder basin) of interactions between bull trout and brook trout. Non-lethal stomach samples were collected and direct observation of interactions conducted. 


\section{Table of Contents}

I. Section 1

Analysis of the genetic structure of Oregon bull trout

pooulations. .....

Page

II. Section 2

Distribution and habitat use of bull trout and brook trout in streams containing both species.

III. Section 3

Bull trout spawning surveys.

IV. Section 4

Summary and analysis of historical juvenile bull trout downstream migrant trap catches in the

Grande Ronde basin......

V. Section 5

Food habits and feeding behavior of bull trout alone and in

sympatry with brook trout.

VI. Reterences........ 


\section{Section 1 \\ ANALYSIS OF THE GENETIC STRUCTURE OF OREGON BULL TROUT POPULATIONS \\ Introduction}

The following is a summary of results presented in Spruell and Allendorf (1997). It is included in this report to briefly present the results of the analysis of genetic samples collected by this project in 1995. For more detailed information please refer to the original report.

We collected non-lethal fin clips from 42 Oregon bull trout populations in 1997 (Hemmingsen et al. 1996). Dr. Paul Spruell of the University of Montana analyzed the samples to identify the genetic characteristics of the populations. The analysis was performed using four polymorphic loci from nuclear satellite DNA , by polymerase chain reaction and DNA sequencing techniques (Spruell and Allendorf 1997). In interpreting the results of the analysis, previous studies of bull trout population genetics using allozyme analysis (Leary et al. 1993) and mitichondrial DNA (Williams et al. 1997) were also considered.

\section{Results and Discussion}

Low levels of genetic variation was identified within bull trout populations. However, substantial variation was observed between populations. These results tend to support the use of the "metapopulation" model in describing bull trout populations (Rieman and Mclntyre 1993). Within populations few different alleles were observed and no population had different alleles in all four of the loci tested. Low levels of heterozygosity were also observed within populations. This suggests that Oregon bull trout populations originated from small founder populations or have persisted at low numbers for several generations.

Analysis of genetic variation between populations identified three major lineages in Oregon; Coastal, Klamath, and inland. Coastal populations include those west of the mouth of the Deschutes River. This group is further subdivided between Hood River populations and all others in the group. It was also noted that there are substantial differences between upper and lower Deschutes populations.

The largest number of Oregon bull trout populations fall within the "inland" group which includes those populations east of the mouth of the John Day River. The largest subdivision within the inland group is between Malhuer populations and all other inland stocks. The greatest difference between groups was between Inland and Coastal groups. Though the mouths of the John Day and Deschutes rivers are only separated by 25 kilometers geographically there is a greater genetic difference between coastal and inland populations than was found between North American and European stocks of Atlantic salmon by researchers using the same technique. Because of these differences it appears that coastal and inland populations arose from separate colonization events. 
The Klamath populations are most closely associated with populations from the Deschutes but are considered to represent a separate lineage. This group is characterized by very low levels of genetic variation identified by both satellite DNA and allozyme analysis. There was a total absence of genetic variation for the satellite DNA loci examined within this group. The population all had the same alleles, the most common alleles observed in the coastal group, at all four loci. However allozyme analysis (Leary et al. 1993) identified a unique allozyme in the Klamath populations. This suggests that Klamath are indeed a genetically unique population.

Spruell and Allendorf (1997) concluded that the Genetic Conservation Groups (GCG) established by the Oregon Department of Fish and Wildlife (Kostow 1995) represent the genetic structure of Oregon bull trout populations fairly well. However, they also note that Hood River populations are genetically distinct and should be assigned their own GCG. Genetic differentiation between Malheur populations and Powder River and Pine Creek populations, currently grouped together in the Malheur GCG, should also be taken into consideration when management decisions are made. The data also indicates that each bull trout population represents a major proportion of the total genetic diversity of the species. Many populations of bull trout must persist throughout their range to preserve genetic diversity. 

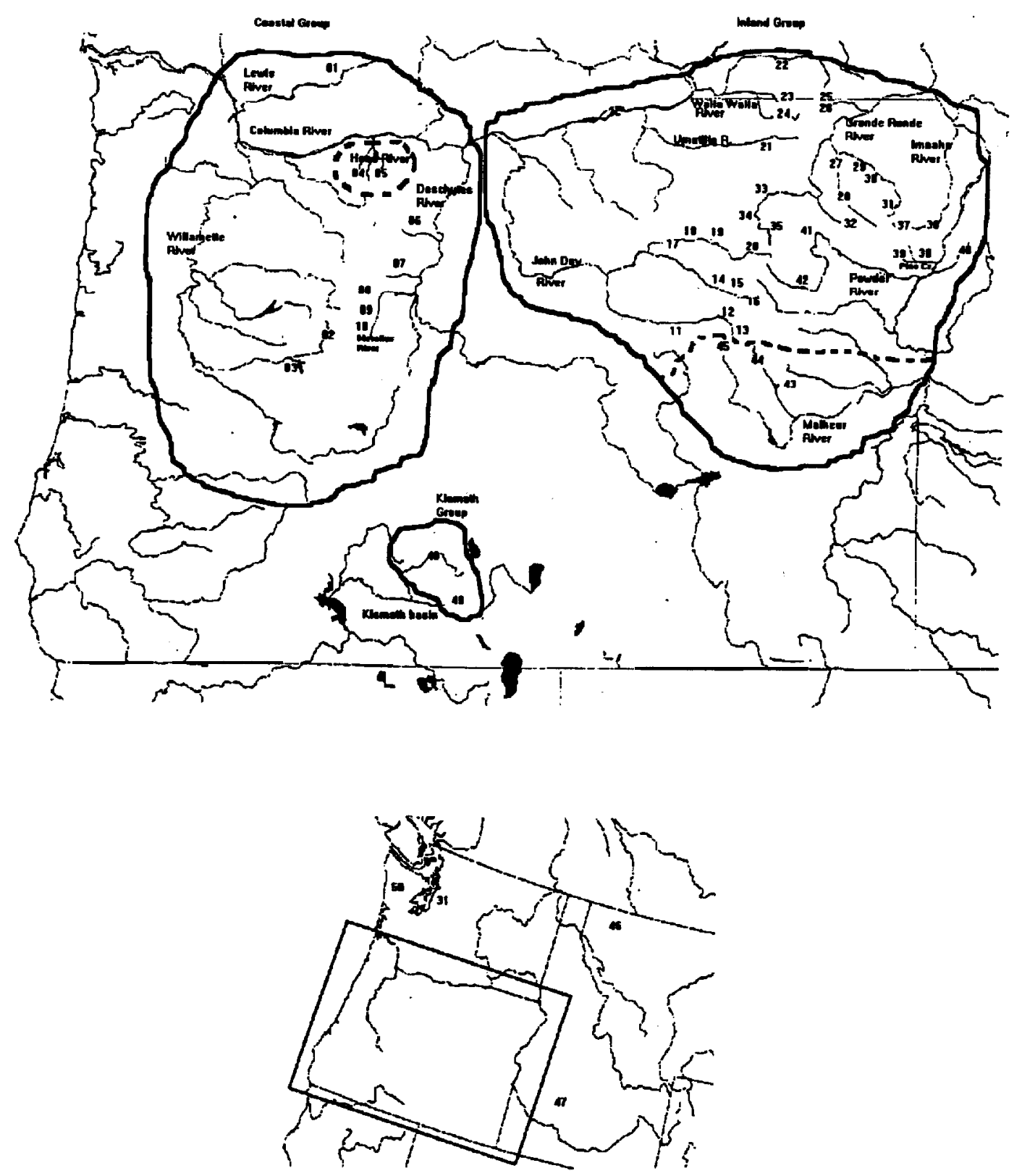

Figure 1.1. Locations of sample sites and genetic groupings. Subgroups within each group are represented by dotted lines (Modified from Spruelll and Allendorf 1997). 
Table 1.1. Sample sites and abbreviations (from Spruell and Allendorf 1997)

\begin{tabular}{|c|c|c|c|c|}
\hline Basin & Subbasin & Population & abbrev. & Map* \\
\hline Lewis River (WA) & Lewis River & Swith Reservoir & SWFT & 01 \\
\hline Willamette River & McKenzie River & $\begin{array}{l}\text { S.F. McKenzie River } \\
\text { Anderson Cr. }\end{array}$ & $\begin{array}{l}\text { SMCK } \\
\text { ANDR }\end{array}$ & $\begin{array}{l}02 \\
03 \\
\end{array}$ \\
\hline Hood River & MiddleFork Hood River & $\begin{array}{l}\text { Clear Branch Cr. } \\
\text { Compasa Cr. }\end{array}$ & $\begin{array}{l}\text { CLBR } \\
\text { COMP }\end{array}$ & $\begin{array}{l}04 \\
05 \\
\end{array}$ \\
\hline Deschutes River & $\begin{array}{l}\text { Warm Springs River } \\
\text { Shitke Cr. } \\
\text { Metollus River }\end{array}$ & $\begin{array}{l}\text { Warm Springs R. } \\
\text { Shitike Cr. } \\
\text { Whitewater River } \\
\text { Jefferson Cr. } \\
\text { Jack Cr. }\end{array}$ & $\begin{array}{l}\text { WMSP } \\
\text { SHTK } \\
\text { WHIT } \\
\text { JEFF } \\
\text { JACK }\end{array}$ & $\begin{array}{l}06 \\
07 \\
06 \\
09 \\
09\end{array}$ \\
\hline John Day River & $\begin{array}{l}\text { Upper John DayRiver } \\
\text { Middle Fork John Day R. } \\
\text { North Fork John Day R. }\end{array}$ & $\begin{array}{l}\text { Upper John Day R. } \\
\text { Indian C r . } \\
\text { Call Cr. } \\
\text { Granite Boulder Cr. } \\
\text { Big Cr. } \\
\text { Clear Cr. } \\
\text { S.F. Desolation Cr. } \\
\text { BaldyCr. } \\
\text { Upper N.F. John Day } \\
\text { Clear Cr. }\end{array}$ & $\begin{array}{l}\text { UJND } \\
\text { JDIN } \\
\text { CALL } \\
\text { GRNB } \\
\text { BIGC } \\
\text { CLRC } \\
\text { SDES } \\
\text { BALD } \\
\text { UNJD } \\
\text { CLER }\end{array}$ & $\begin{array}{l}11 \\
12 \\
13 \\
14 \\
15 \\
16 \\
17 \\
16 \\
19 \\
20\end{array}$ \\
\hline UmatilaRiver & N.F. Umedilla R. & N.F.Umatilla & NUMA & 21 \\
\hline WallaWalia R. & $\begin{array}{l}\text { Touched R. (WA) } \\
\text { Mill Cr. } \\
\text { S.F. Walla Walla }\end{array}$ & $\begin{array}{l}\text { N.F. Touchet } \\
\text { Mill Cr. } \\
\text { S.F.WallaWalla }\end{array}$ & $\begin{array}{l}\text { NTOU } \\
\text { MILL } \\
\text { SWAL }\end{array}$ & $\begin{array}{l}22 \\
23 \\
24 \\
\end{array}$ \\
\hline Grand Ronde $R$. & $\begin{array}{l}\text { WenahaR. } \\
\text { Minam River } \\
\text { CatherineCr. } \\
\text { Upper Grande Ronde }\end{array}$ & $\begin{array}{l}\text { S.F. Wenaha } \\
\text { S.F. Butte Cr. } \\
\text { Elk Cr. } \\
\text { Little Minam R. } \\
\text { Bear Cr. } \\
\text { Lostine River } \\
\text { HumbaneCr. } \\
\text { N.F. Catherine Cr. } \\
\text { Indiin Cr. } \\
\text { Limber Jim Cr. } \\
\text { Clear Cr. }\end{array}$ & $\begin{array}{l}\text { SWEN } \\
\text { BUTE } \\
\text { ELCR } \\
\text { LMIN } \\
\text { BEAR } \\
\text { LOST } \\
\text { JURR } \\
\text { NCAT } \\
\text { INDN } \\
\text { LJIM } \\
\text { CEAR } \\
\end{array}$ & $\begin{array}{r}25 \\
26 \\
27 \\
-26 \\
29 \\
30 \\
31 \\
32 \\
33 \\
34 \\
35 \\
\end{array}$ \\
\hline Imraha River & $\begin{array}{l}\text { N.F. ImnahaRiver } \\
\text { Big Sheep Cr. }\end{array}$ & $\begin{array}{l}\text { N.F. Imnaha } \\
\text { Lick Cr. }\end{array}$ & $\begin{array}{l}\text { NIMN } \\
\text { LICK }\end{array}$ & $\begin{array}{l}36 \\
37\end{array}$ \\
\hline Pinecreek & & $\begin{array}{l}\text { E.F. Pine Creek } \\
\text { ElkCreek }\end{array}$ & $\begin{array}{l}\text { EPIN } \\
\text { ELKC }\end{array}$ & $\begin{array}{l}36 \\
39\end{array}$ \\
\hline Snake Rlver & Indii Cr. (D) & IndianCreek & INDI & 40 \\
\hline Pounder R i i & $\begin{array}{l}\text { North Pouder T. } \\
\text { Upper Pounder River }\end{array}$ & $\begin{array}{l}\text { N.F. Powder Rii } \\
\text { Silver Cr. }\end{array}$ & $\begin{array}{l}\text { NPOW } \\
\text { SILV }\end{array}$ & $\begin{array}{l}41 \\
42\end{array}$ \\
\hline Mahuer River & $\begin{array}{l}\text { Beada Reservoir } \\
\text { N.F.Mhaheur River }\end{array}$ & $\begin{array}{l}\text { Beaula Reservoir } \\
\text { Swanp Creek } \\
\text { Big Cr. (Meadow Fk) }\end{array}$ & $\begin{array}{l}\text { BULA } \\
\text { SWAM } \\
\text { MEDB } \\
\end{array}$ & $\begin{array}{l}\frac{46}{43} \\
44 \\
45 \\
\end{array}$ \\
\hline Flathoed Basin & Flathead Basin (MT) & & FLHD & 46 \\
\hline Boise River & BolseRher (ID) & & BOIS & 47 \\
\hline Kamath River & $\begin{array}{l}\text { Sprague River } \\
\text { Upper Kanath }\end{array}$ & S.F. Sprague R. & $\begin{array}{l}\text { KLAM } \\
\text { LONG }\end{array}$ & $\begin{array}{l}46 \\
49 \\
\end{array}$ \\
\hline Quets River & QuectsRiver (WA) & QuectsRiver. & QEET & 50 \\
\hline Skaghiver & SaukRher(WA) & SaukRiver & SAUK & 51 \\
\hline
\end{tabular}




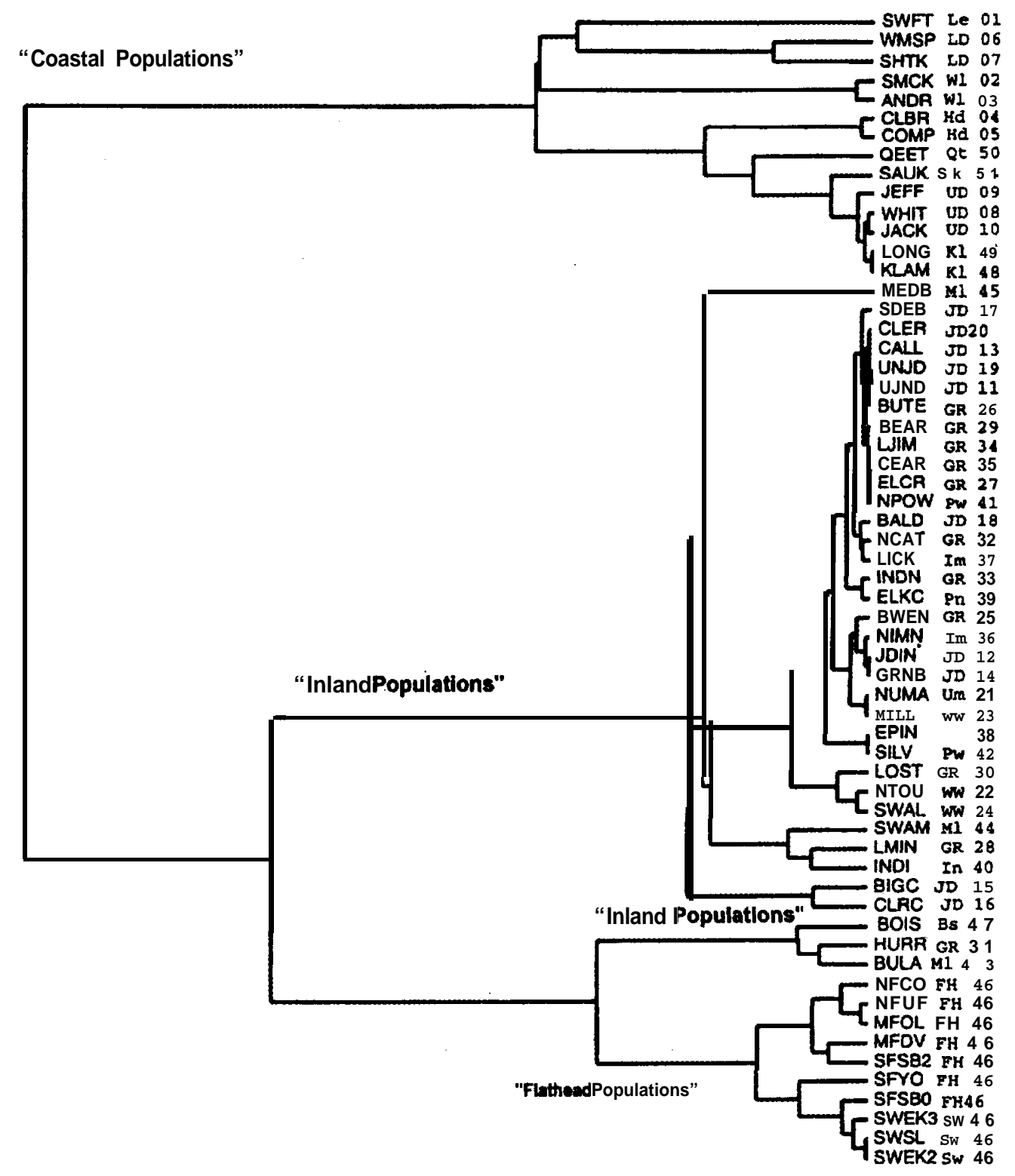

Figure 1.2. Dendrogram of genetic relationships between sampled bull trout populations based on the four microsattelite DNA loci analyzed. Sample number $s$ and abbreviations correspond to those in figure 1.1 (From Spruell and Allendorf 1997). 


\section{SECTION 2 \\ DISTRIBUTION AND HABITAT USE OF BULL TROUT AND BROOK TROUT IN STREAMS CONTAINING BOTH SPECIES}

\section{Introduction}

Interactions with exotic brook trout are considered to represent a significant threat to bull trout populations (Ratliff and Howell, 1992). In addition to potential direct competition for food and habitat brook trout have been observed to hybridize with bull trout (Markle 1992; Ratliff and Howell, 1992; Kitano et al., 1996). Brook trout may even hybridize with much larger fluvial bull trout by employing "sneak male" tactics, with the smaller male brook trout darting in to deposit his milt as pairs of bull trout spawn (Kitano et al., 1996).

In many areas brook trout appear to have displaced bull trout. Reaches of streams where bull trout were historically present now often only contain brook trout. However, bull trout are not always displaced by brook trout and many sympatric populations have been identified within Oregon. In addition to brook trout introductions habitat conditions in areas formerly occupied by bull trout have changed. Bull trout are extremely sensitive to high water temperatures and siltation. These two factors have increased significantly due to riparian degradation in the lower ends of most bull trout streams.

Present distributions of sympatric populations bull trout and brook trout in Oregon are the result of up 90 years of interaction. This study seeks to identify factors affecting present bull trout distribution and identify habitat characteristics by which bull trout and brook trout partition available stream habitat.

\section{Methods}

We selected streams to survey from fish distribution information provided by the Oregon Department of Fish and Wildlife (ODFW) Aquatic Inventory Project, ODFW district biologists and U.S. Forest Service (USFS) biologists. Sampling was conducted from 25 June - 29 August 1996.

\section{Fish Distribution}

We used a systematic sampling strategy to assess fish distribution. Beginning at the mouth of the stream or $2 \mathrm{~km}$ below the lower limit of bull trout distribution (determined from previous surveys) a $100 \mathrm{~m}$ section was sampled in every kilometer as we moved upstream. This gave a 10\% sampling rate which has been suggested by other researchers (Hillman and Platts, 1993) for the detection of bull trout at low densities. When the limits of a species distribution were detected an additional $100 \mathrm{~m}$ section was sampled between the sample where the species was last observed and the sample where they were absent. This allowed estimation of species distribution to a precision of $\pm 500 \mathrm{~m}$. Sampling was conducted by making 
a single pass with a DC electroshocker. Electroshocker settings were selected to minimize chances of injury to fish by examining injury rates observed at various settings from sampling conducted in 1995 (Hemmingsen et al. 1996). After capture fish were identified to species, measured and released into the section in which they were captured.

\section{Habitat}

Habitat surveys were conducted within zones of distribution identified by fish sampling using the protocol established by the ODFW Aquatic Inventory Project (Moore et. al, 1996). The surveys include measurements of habitat type, substrate, gradient, instream cover, woody debris, and bank condition. The protocol was slightly modified by eliminating detailed riparian zone analysis and using it to subsample the stream rather than sampling the entire stream. Approximately $2 \mathrm{~km}$ of habitat was surveyed within zones of allopatric bull trout and brook trout distribution in evenly distributed $500 \mathrm{~m}$ sections. An additional $500 \mathrm{~m}$ was surveyed in the zone of sympatry.

\section{Temperature}

Electronic temperature loggers ("hobo-temp", Onset Computer Co.) were placed in zones of distribution identified by fish surveys. The temperature loggers remained in place for approximately 30 days.

\section{Resutts and Discussion}

We completed surveys in 10 streams in the North Fork John Day, Metolius, and Powder Basins. Partial data was gathered from 3 additional streams which were not completely sampled due to limitations imposed by forest fires and time constraints. Statistical analysis conducted before we began this project suggested we would need to survey 15-20 streams to have an acceptable level of statistical power. We completed 10 streams in 1996 and plan to complete another 6-8 streams in 1997. Preliminary results of surveys will be presented here. Detailed analysis of temperature and other habitat factors will be presented in the 1997 report after the target number of 15-20 surveys have been completed.

\section{Patterns of Distribution}

Lengths of distribution zones for sampled streams are listed in Table 2.1. Not all streams included all three types of distribution zones. Some streams included only allopatric bull trout or brook trout zones and a zone of sympatry. In most streams the sympatric zone was relatively short in comparison to the allopatric zones. It should also be remembered in most cases the allopatric brook trout zone actually continued down stream beyond the lower limits of the survey. 
Maps of general patterns of distribution observed in streams are illustrated in Figures 2.1-2.5. In most cases bull trout distribution was confined to the upper reaches of the stream bounded on its downstream end by brook trout. However, in the case of streams with a lake located in the headwaters this pattern may be reversed (Figures 2.3 and 2.5). The alpine lakes found at the headwaters of these streams were very popular locations for brook trout introductions.

\section{Brook Trout/ Bull Trout Hybrids}

In the course of our surveys we also looked for bull trout/brook trout hybrids. We used characteristics noted by Markle (1992) dark spots on the dorsal fin, vermiculation on the back and tricolor ventral fins to identify hybrids. Non lethal fin clips were also collected and preserved in ETOH for later DNA analysis to confirm our identification. We found hybrids in three streams, North Fork Anthony Creek, Cunningham Creek, and the upper North Powder River. The range of hybrids within the stream was the same as that of brook trout in Cunningham Creek and the North Powder River but overlapped with allopatric bull trout distribution in North Fork Anthony Creek.

\section{Length Frequencies}

Length frequencies for were pooled by basin for analysis. Length frequencies of brook trout and bull trout captured in the North Fork John Day, Metolius and Powder basins are illustrated in Figures 2.6-2.8. Bull trout length frequencies generally show 3-4 peaks associated with age $0+, 1,2$ and 3 fish. this agrees with accounts of other authors who report that most bull trout emigrate at ages 2-3 (Pratt, 1992). Only 2 bull trout longer than $200 \mathrm{~mm}$ were observed in our samples. Mean fork lengths are summarized in Table 2.2. There was no significant difference between mean lengths of bull trout and brook trout in areas of sympatry (table 2.3). However, the mean fork length of bull trout in areas of sympatry $(128.0 \mathrm{~mm})$ was found to be significantly greater $(p=0.05)$ than the mean length of bull trout in zones of allopatry (113.6 mm).

Bull trout length frequencies from fish captured in this study confirm that most juveniles emigrate at age 2-3 or grow much slower than migratory fish in the basins sampled. (Nakano et al., in press) observed that bull trout and brook trout form interspecific size structured feeding hierarchies in pools in Montana. The observation that the mean fork length of bull trout from zones of sympatry is longer than those from allopatric zones suggests that smaller bull trout may not fare well in such hierarchies. Additionally since they emigrate after 2-3 years bull trout populations may be at a disadvantage to brook trout who remain in the streams and continue to grow. 
Table 2.1. Lengths of distribution zones of bull trout and brook trout in streams containing both species. All distribution limits are $\pm 500 \mathrm{~m}$, Numbers of fish are based mean numbers of fish captured from 1 -pass electrofishing of a $100 \mathrm{~m}$ section.

\begin{tabular}{|c|c|c|c|c|c|c|c|c|c|c|}
\hline & \multicolumn{2}{|c|}{$\begin{array}{c}\text { Bull Trout } \\
\text { Zone }\end{array}$} & \multicolumn{3}{|c|}{ Sympatric zone } & \multicolumn{2}{|c|}{$\begin{array}{c}\text { Brook Trout } \\
\text { Zone }\end{array}$} & \multicolumn{2}{|c|}{$\begin{array}{c}\text { BRK/BULL } \\
\text { Hybrid }\end{array}$} & \multirow[b]{2}{*}{\begin{tabular}{|l}
$\begin{array}{l}\text { Stream length } \\
(\mathrm{km})\end{array}$ \\
\end{tabular}} \\
\hline & $\begin{array}{l}\text { Length } \\
(\mathrm{km})\end{array}$ & $\begin{array}{ll}\mathrm{Bul} \\
\mathrm{fuodm}\end{array}$ & $\begin{array}{l}\begin{array}{l}\text { Length } \\
(\mathrm{km})\end{array} \\
\end{array}$ & $\begin{array}{l}\mathrm{BUL} \\
/ 100 \mathrm{~m}\end{array}$ & $\begin{array}{l}\text { BRK } \\
\text { lloom }\end{array}$ & $\begin{array}{l}\text { Length } \\
(\mathrm{km})\end{array}$ & $\begin{array}{l}\text { BRK } \\
1100 \mathrm{~m}\end{array}$ & $\begin{array}{l}\text { Length } \\
(\mathrm{km})\end{array}$ & \begin{tabular}{|l}
$\mathrm{HYB}$ \\
$\mathrm{H} 100 \mathrm{~m}$
\end{tabular} & \\
\hline \multicolumn{11}{|c|}{ North Fork John Day River } \\
\hline Crane Cr. & & & 0.5 & 4 & 1 & 12.2 & 4.7 & & & 13.75 \\
\hline Baldy Cr. & 5.5 & 8.5 & 1.0 & 4.5 & 1.5 & 1.0 & 1 & & & 8.0 \\
\hline $\begin{array}{l}\text { Cunningham } \\
\text { Cr. }\end{array}$ & 0.5 & 1.5 & & & & & & 0.5 & 1 & 1.75 \\
\hline Crawfish Cr. & & & 1.0 & 5 & 12 & 4.5 & 17.8 & & & 6.0 \\
\hline \multicolumn{11}{|l|}{ Metolius River } \\
\hline Canyon $\mathrm{Cr}$. & 3.8 & 3.6 & 2.5 & 0.5 & 3.3 & 8.4 & 4.0 & & & 18.25 \\
\hline Roaring $\mathrm{Cr}$. & 2.5 & 3.7 & & & & & & & & 2.75 \\
\hline \multicolumn{11}{|l|}{ Powder River } \\
\hline $\begin{array}{l}\text { NF Anthony } \\
\text { Cr. }\end{array}$ & 4.0 & 7.8 & 0.5 & 2 & 4 & .75 & 2.5 & 4.0 & 1 & 8.2 \\
\hline Indian Cr. & 2.5 & 9 & 0.75 & 9.5 & 1.5 & 2.4 & 1.5 & & & 7.0 \\
\hline Lake Cr. & 2.5 & 4.7 & & & & 1.0 & 1.5 & & & 7.5 \\
\hline $\begin{array}{l}\text { Little Cracker } \\
\text { Cr. }\end{array}$ & 0.5 & 1 & 0.5 & 2 & 3 & & & & & 3.0 \\
\hline $\begin{array}{l}\text { Upper North } \\
\text { Powder River }\end{array}$ & 1.0 & 5.3 & 1.5 & 1.0 & 34.7 & $7.5^{\star}$ & 34.3 & 2.0 & 1.8 & \begin{tabular}{|c|} 
Upper \\
id.5 \\
sampled
\end{tabular} \\
\hline
\end{tabular}

BRK= Brook Trout, BUL=Bull Trout, HYB= Bull trout/Brook trout hybrid. *Estimate, may continrse further down stream 
Table 2.2. Summary of bull trout and brook trout mean fork lengths by basin.

\begin{tabular}{|c|c|c|c|c|c|c|c|c|}
\hline \multicolumn{3}{|c|}{ Overall Summary } & \multicolumn{2}{|c|}{$\begin{array}{l}\text { North Fork } \\
\text { John Day }\end{array}$} & \multicolumn{2}{|c|}{ Metolius } & \multicolumn{2}{|c|}{ Powder } \\
\hline & BUT & BRK & BUT & BRK & BUT & BRK & BUT & BRK \\
\hline \multirow{6}{*}{$\begin{array}{l}\text { Mean } \\
\text { Std Dev } \\
\text { Median } \\
\text { Max } \\
\text { Min } \\
n\end{array}$} & $116.3^{*}$ & $132.1^{*}$ & 124.6 & 129.2 & $67.7^{\star}$ & $128.6^{*}$ & 132.0 & 134.0 \\
\hline & 42.1 & 36.1 & 35.7 & 32.3 & 37.5 & 33.0 & 30.7 & 38.3 \\
\hline & 122 & 138 & 131 & 132.5 & 50 & 124 & 130 & 140 \\
\hline & 222 & 220 & 202 & 186 & 176 & 195 & 222 & 220 \\
\hline & 25 & 45 & 56 & 65 & 25 & 80 & 60 & 45 \\
\hline & 233 & 385 & 67 & 126 & 49 & 25 & 117 & 234 \\
\hline
\end{tabular}

${ }^{*}$ Significantly different at $P=0.05$

Table 2.3. Mean fork lengths of bull trout and brook trout from overlap zones pooled for all basins.

\begin{tabular}{|c|c|c|}
\hline \multicolumn{3}{|c|}{ Overall summary } \\
\hline \multirow{7}{*}{$\begin{array}{l}\text { mean } \\
\text { stdev } \\
\text { median } \\
\text { max } \\
\text { min } \\
n\end{array}$} & BRK & BUT \\
\hline & $\overline{122.2}$ & $\overline{128.0}$ \\
\hline & $\overline{42.0}$ & 33.0 \\
\hline & 124 & 126 \\
\hline & 210 & 222 \\
\hline & 45 & 70 \\
\hline & 264 & 47 \\
\hline
\end{tabular}




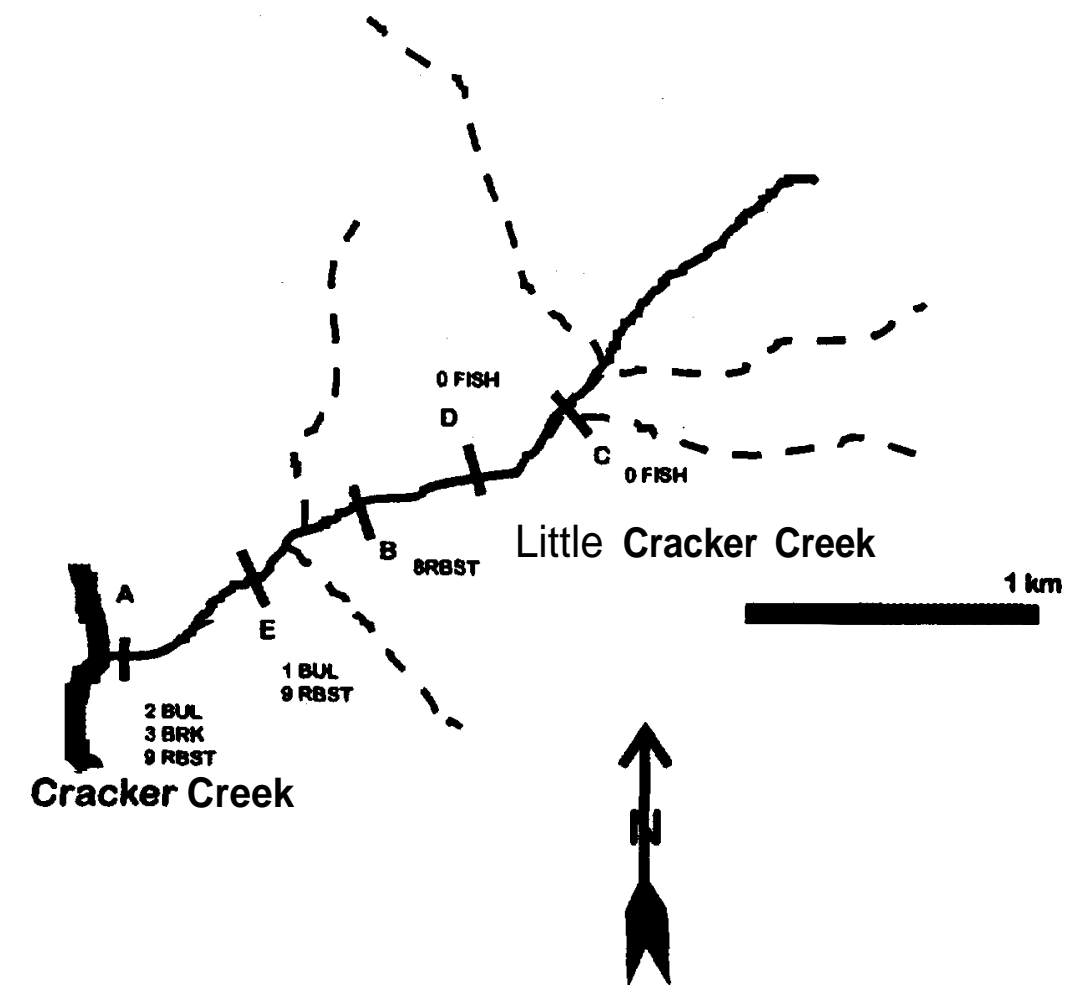

Figure 2.1. Little Cracker Creek, Powder River Drainage. Bull trout/brook trout sympatric distribution in the lower end of the stream with a very narrow section of bull trout allopatric distribution. $\mathrm{BUL}=$ bull trout, $\mathrm{BRK}=$ brook trout, $\mathrm{HYB}=$ bull -trout/brook trout hybrid, RBST = rainbow trout/steelhead. 


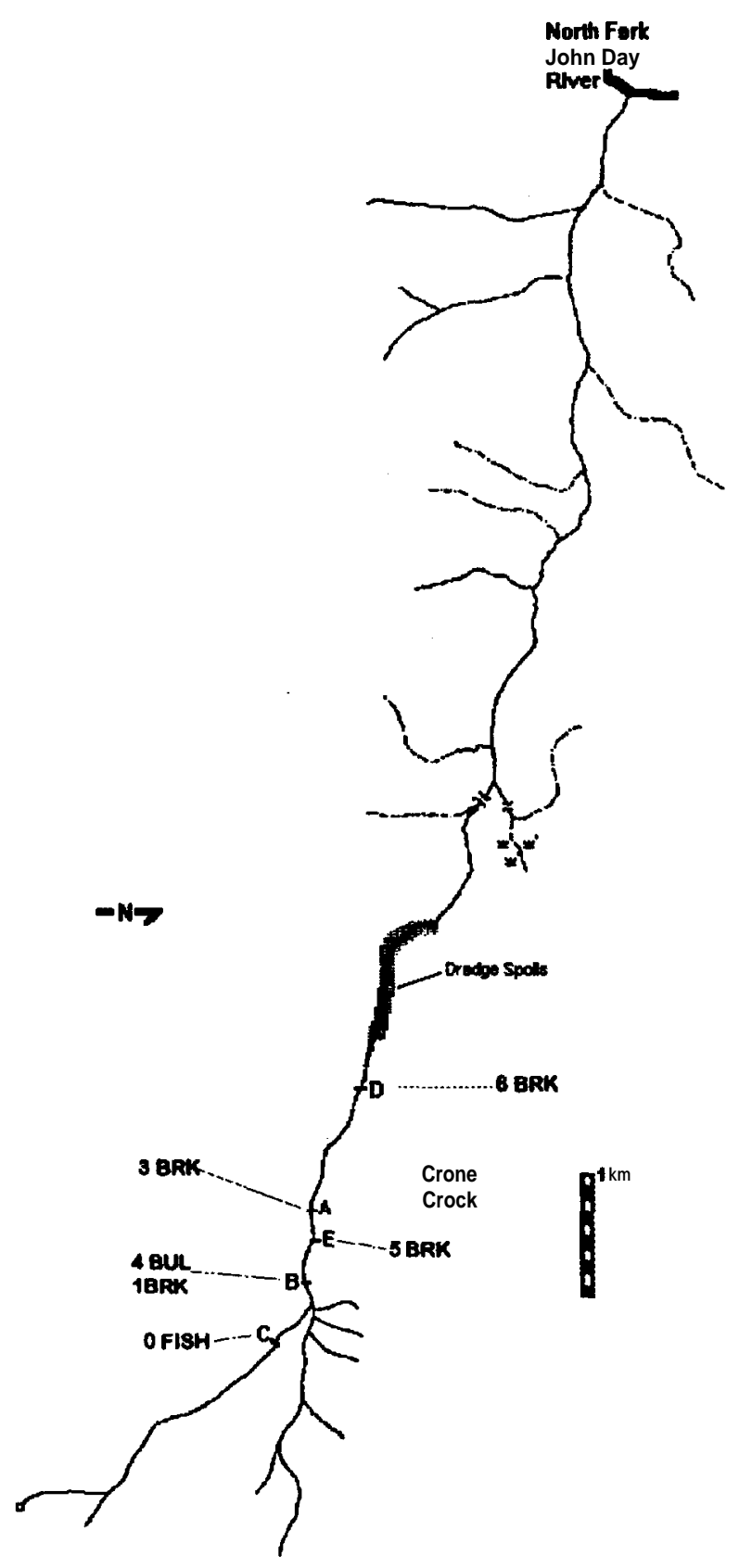

Figure 2.2. Crane Creek, North Fork John Day Drainage. Allopatric brook trout distribution upstream to a short reach of bull trout/brook trout sympatric distribution. There are accounts of fishermen going to the mouth of Crane creek to fish for bull trout in the 1940's (Claire and Gray 1993). BUL= bull trout, BRK = brook trout, HYB = bull trout/brook trout hybrid, RBST = rainbow trout/steelhead. 


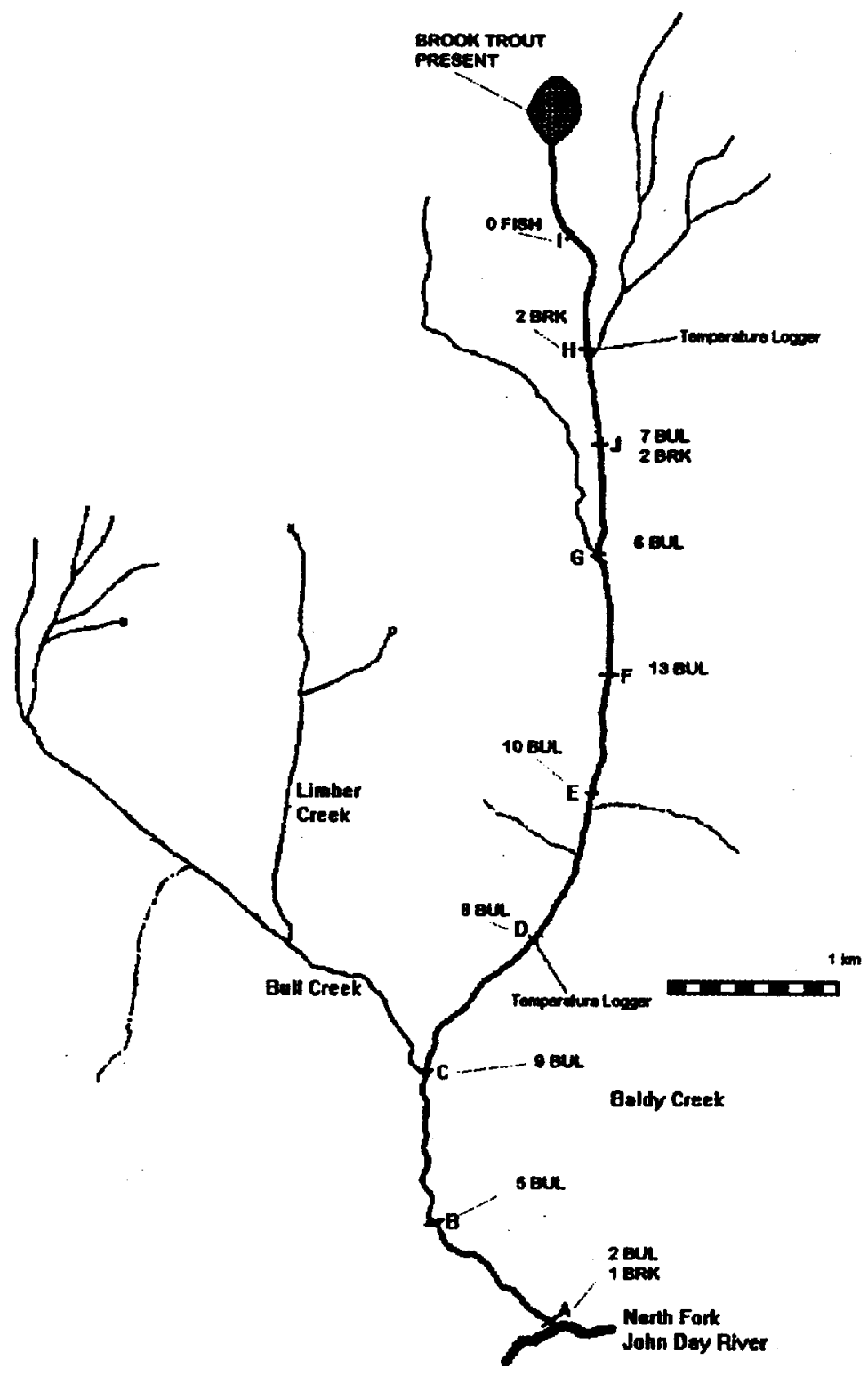

Figure 2.3. Baldy Creek, North Fork John Day Basin. Allopatric bull trout distribution from the mouth of the stream up to a relatively short zone of sympatry followed by a zone of allopatric brook trout distribution. In this case there are actually some brook trout at the mouth of the stream they probably moved into the stream from the North Fork John Day. This pattern was only observed in streams with a lake at the headwaters (these alpine lakes were often stocked with bull trout). Other examples include Canyon Creek and Lake Creek. BUL= bull trout, BRK = brook trout, HYB = bull trout/brook trout hybrid, RBST = rainbow trout/steelhead. 


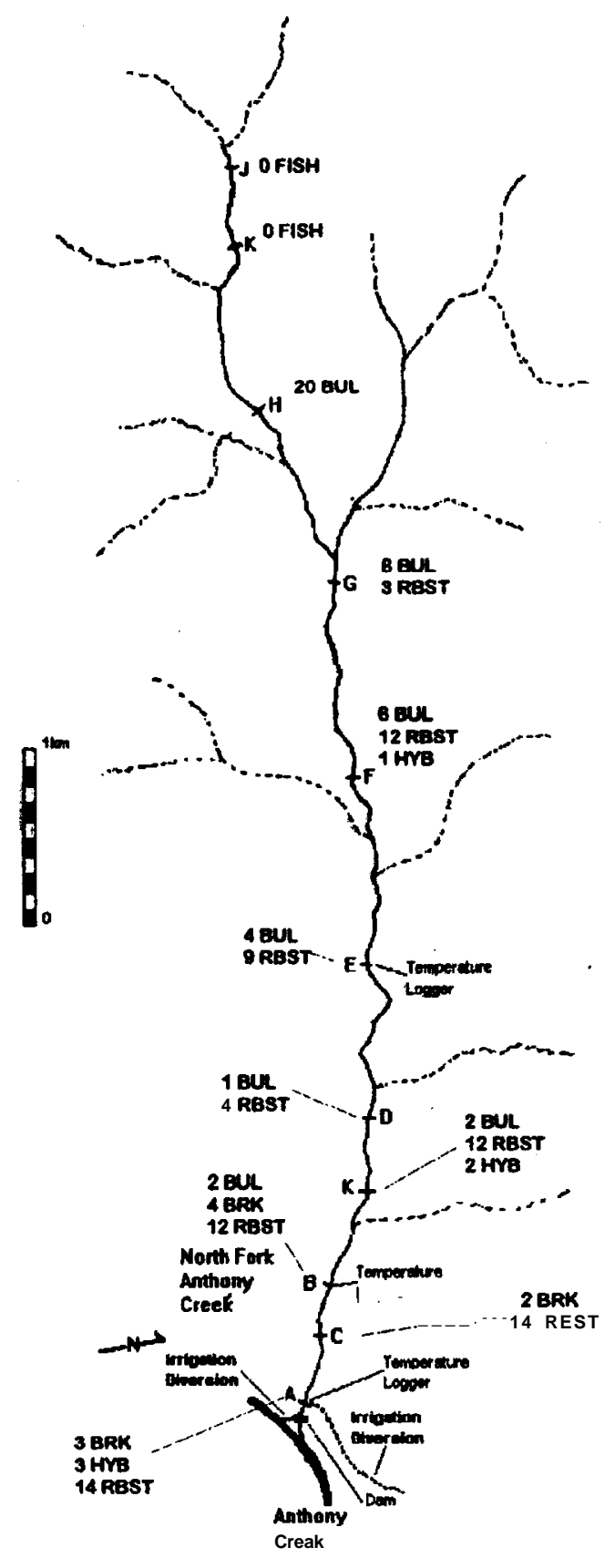

Figure 2.4. North Fork Anthony Creek, Powder Drainage. Allopatric brook trout distribution from the mouth upstream to a short zone of sympatry followed by allopatric bull trout distribution to the upstream limits of fish distribution. In this stream the route of brook trout invasion was from downstream. Other examples include Indian Creek and Upper North Powder River. BUL= bull trout, BRK = brook trout, HYB = bull trout/brook trout hybrid, RBST = rainbow trout/steelhead. 


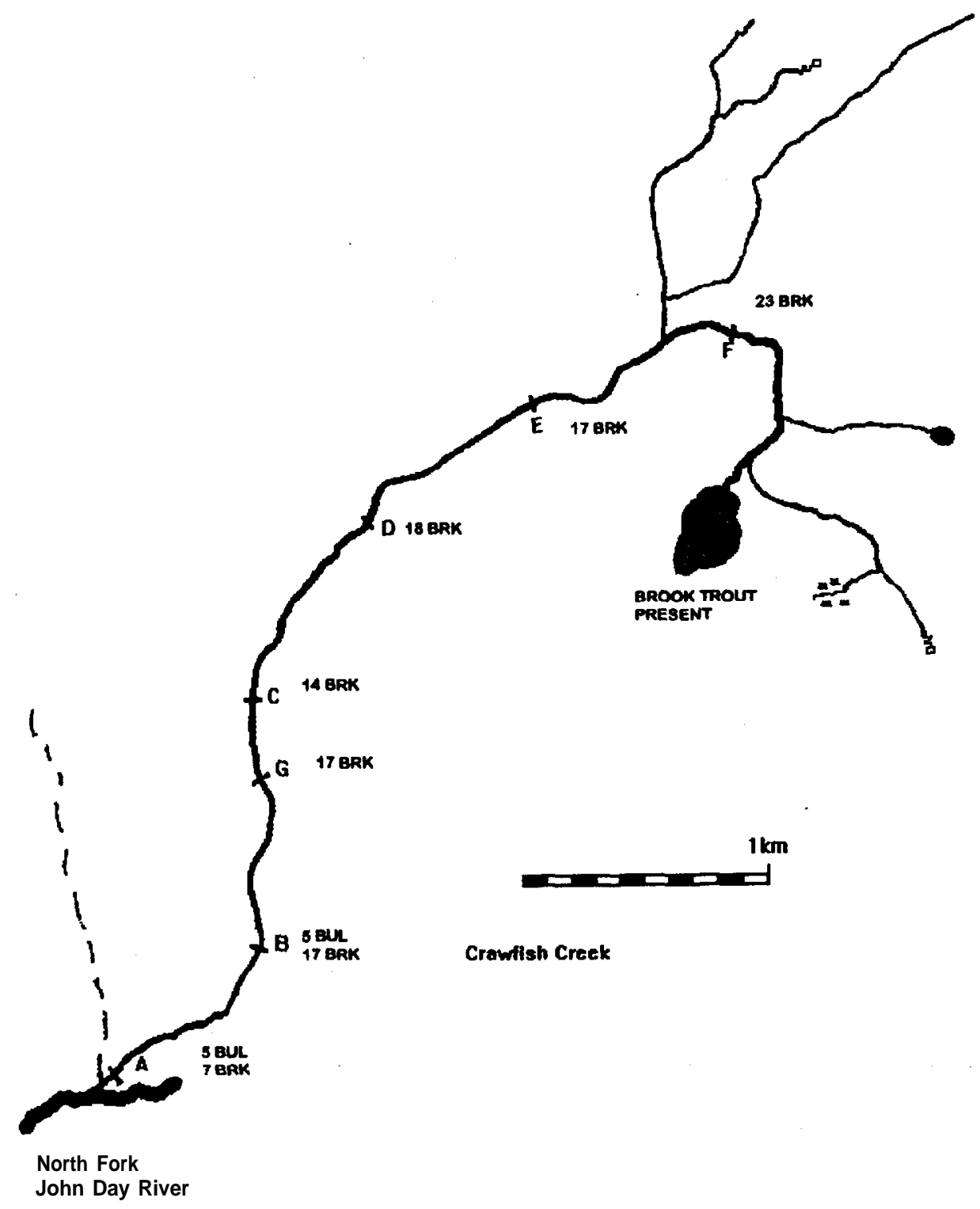

Figure 2.5. Crawfish Creek, North Fork John Day River. A relatively short zone of bull trout/brook trout sympatry at near the mouth with allopatric brook trout distribution upstream to an alpine lake containing brook trout. 
Figure 2.6. Length frequencies of bull trout and brook trout caught in the Metolius Basin.

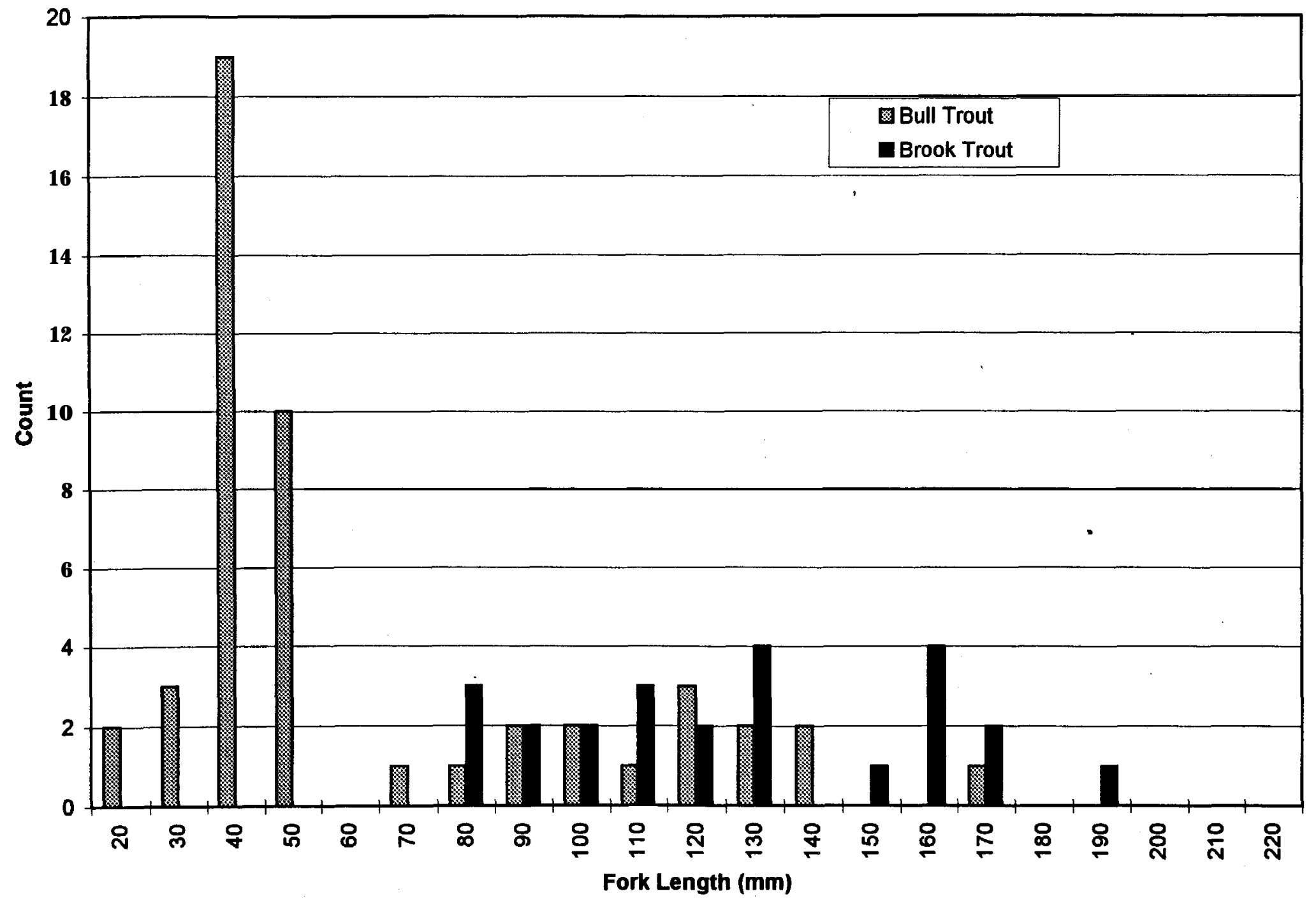


Figure 2.7. Length frequencies of bull trout and brook trout caught in the Powder Basin.

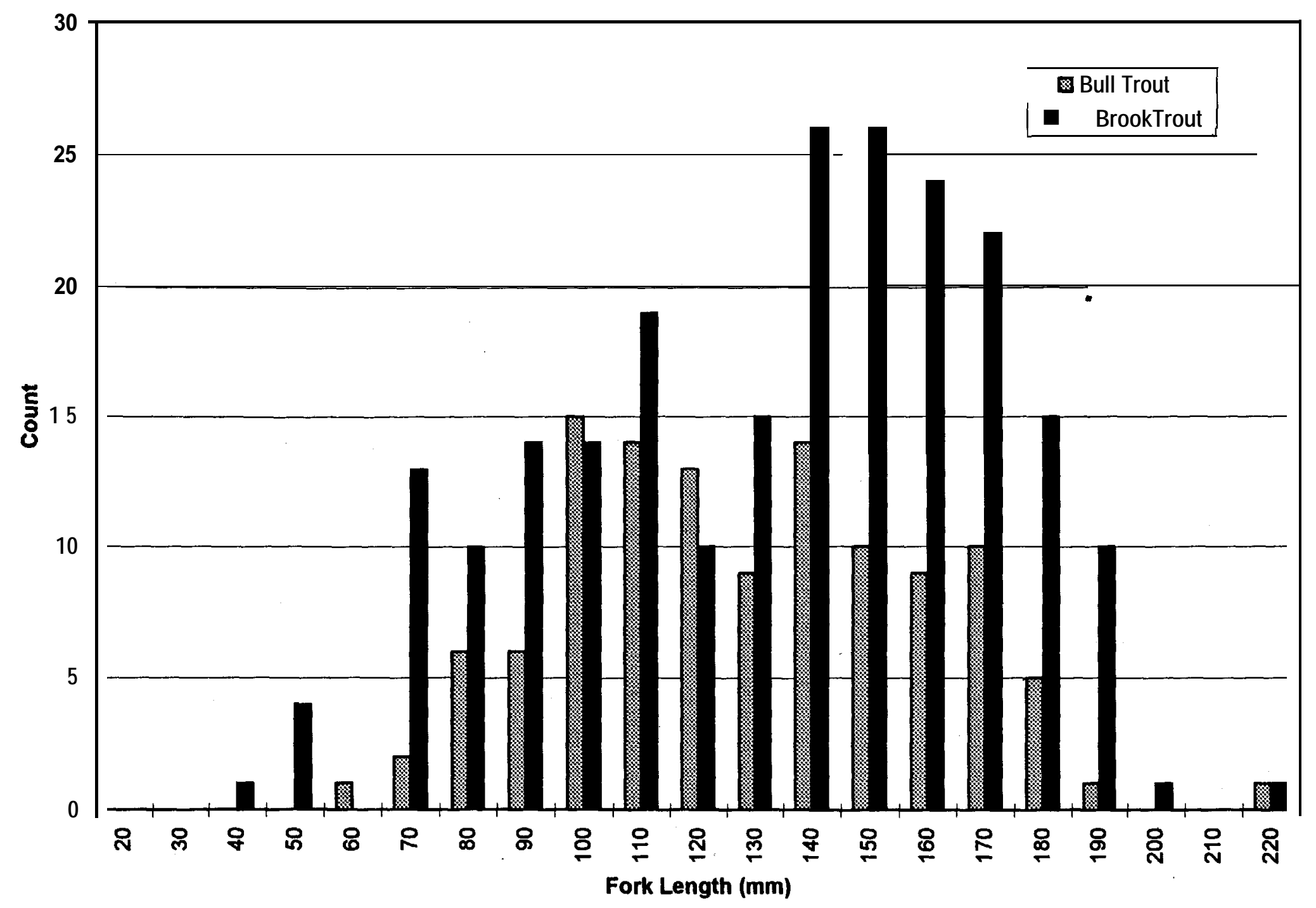


Figure 2.8. Length frequencies of bull trout and brook trout caught in the North Fork John Day Basin.

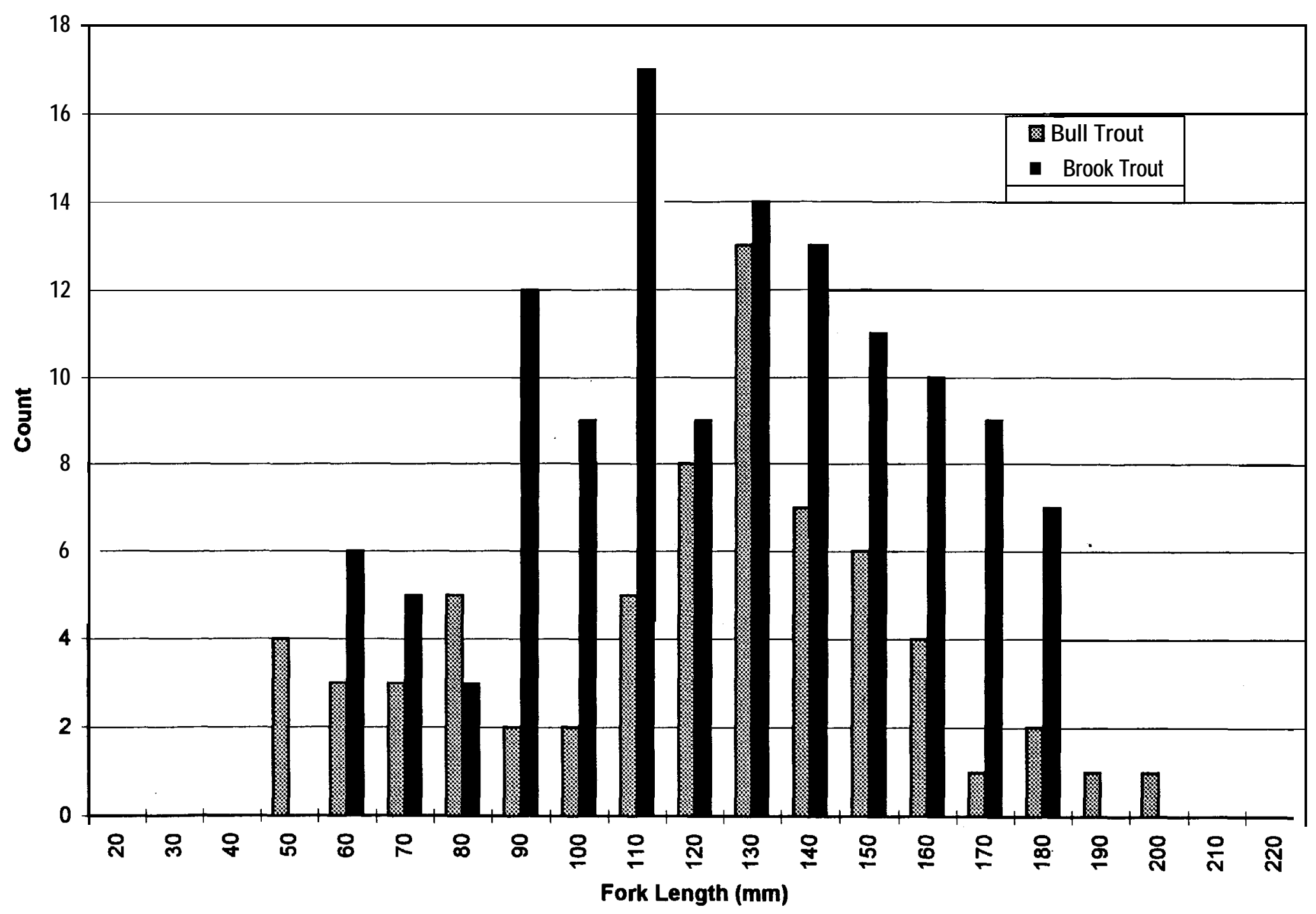




\section{SECTION 3 \\ BULL TROUT SPAWNING SURVEYS}

\section{Introduction}

In Oregon, most bull trout populations spawn in September and October, though populations in the Metolius River basin begin spawning in July. Fluvial and adfluvial spawners may migrate long distances to reach spawning streams. Most populations reach spawning streams in June or July and hold there until spawning begins in October. Radio tagged bull trout in the Metolius river began their spawning migrations May-August (Thiesfield et al., 1996). However, other populations may begin as early as April and complete their migrations by July (Thiesfield et al., 1996). Migrations into tributaries may also be prompted by high water temperature, with non-spawning bull trout seeking refuge in the cooler water (Swanberg, 1996) The spawning habits of resident populations are not as well known. Spawners in these populations are much smaller $(150-300 \mathrm{~mm})$ and since they appear to reside in the same streams in which they spawn a long migration is unlikely.

Bull trout construct a typical salmonid redd. The female excavates the redd and the male defends it from rivals. Bull trout often build redds on the downstream margins of pools in water 0.2-0.8m deep (Pratt, 1992; Kitano et al., 1994)

Our objectives in conducting these studies were: to identify areas where bull trout spawn, identify variation in spawning distribution, identify variation associated with different life history forms, estimate variation among spawning surveyors, and determine appropriate sampling frequency for spawning surveys. By fulfilling these objectives we hope to estimate the potential effectiveness of using spawning surveys to monitor bull trout abundance and provide guidelines for planning accurate surveys.

\section{Methods}

We conducted two types of spawning surveys. Multi-pass surveys were conducted on three streams. We surveyed these streams 3-4 times in September and October. We will continue surveys on these streams through 1999. We conducted single pass surveys. on four streams. Each stream was only surveyed once. Single pass surveys were conducted in late September and early October that we anticipated to be the peak bull trout spawning period. The primary purpose of these surveys was to document areas where bull trout spawn.

\section{Sites}

We selected three streams to conduct our multi-pass surveys . Mill Creek, in the Walla Walla basin, Silver Creek, in the Powder basin and The Little Minam River, in the Grande Ronde basin. 
Spawning areas in Mill Creek are in a closed access watershed and have not been subject to human disturbance. Spawning populations in Mill Creek are mostly large fluvial adults. Mill Creek spawning populations are considered fairly healthy with redd counts of over 120 for several years (M. Northrup, U. S. Forest Service (USFS), Personal communication). Both ODFW and USFS surveyors conducted Mill Creek surveys. Silver Creek is a second order tributary of Cracker Creek. There has been some impact from logging and mining. Silver Creek spawners are small resident fish (20-250 mm). Silver Creek is upstream of Phillips Reservoir that limits potential fluvial migration into the Powder River system. The little Minam River is a tributary of the Minam River. It is located within a designated wilderness area and has experienced little human impact. There is a barrier to fish passage located near the mouth so the spawning population consists of small resident fish.

Single-pass surveys were conducted on the upper North Fork John Day River, North Fork Anthony Creek (Powder River), Baldy Creek (North Fork John Day) and Indian Creek (Powder River). We chose these streams because of the presence of bull trout juveniles detected during distribution surveys.

\section{Survey protocol}

Surveyors counted the number of bull trout redds visible and the number of bull trout $150 \mathrm{~mm}$ or greater in length as they moved either upstream or downstream along designated reaches of a stream (upstream survey was preferred when possible). Stream reaches were designated before surveying and marked on each surveyors map. Reaches were $2-5 \mathrm{~km}$ long and corresponded with changes in stream character. Upstream and downstream limits of reaches were chosen to correspond with terrain features easily identifiable by surveyors.

Bull trout observed which were not engaged in spawning \{holding under cover, etc.) were noted on the fish observation form. Each redd found was assigned a number and recorded, numbers were assigned in order of discovery and not repeated within a reach. The surveyor noted if there were bull trout present on the redd and estimated their length to the nearest $50 \mathrm{~mm}$. Surveyors also looked for and recorded the presence of satellite males (bull trout or brook trout).

We recorded a number of redd characteristics. The distance to the nearest bull trout redd (unless it was more than $20 \mathrm{~m}$ away) was recorded. Water temperature near the redd was recorded. The length of the redd was measured from the front edge of the pocket to the back edge of the mound. Width measured at the widest portion of the redd. Water depth was measured with a wading staff in the deepest part of the pocket and from the stream bottom alongside the redd. Substrate composition was evaluated by a pebble count. A wading staff was-laid parallel to the redd and the number of stones (of any size) which touch a $50 \mathrm{~cm}$ section counted. In the case of areas of sand or silt record the number of centimeters encompassed was recorded. The type of habitat unit the redd occurred in and a general description was also recorded.

If the stream was a single-pass survey the surveyor continued surveying upstream after recording redd data. If the stream was to be surveyed a number of 
times the redd was marked with a plastic flag tied on streamside vegetation near the redd. If the survey was a follow up survey, data on the visibility of previously flagged redds was be gathered. Previously identified redds were examined and visibility evaluated on the following scale: Category 1: redds that look almost new with no algal growth or silt deposition on the redd and the pocket and mound sharply defined. Category 2: redds with some algal growth and silt deposition, but less than the surrounding stream bottom, and with the mound and pocket slightly eroded. Category 3: redds with algal growth and silt deposition the same as surrounding stream bottom and pocket and mound indistinct. We estimate the probability of surveyors detecting redds in class 1 to be the same as the chances of detecting a new red, the chances of detecting a class 2 redd to be $50 \%$ of the chance of detecting a new redd and that it would be very unlikely that a surveyor would be able to detect a class 3 redd. We removed all ODFW bull trout flagging from the reach on the last survey of the season. Variability among surveyors was assessed by having each surveyor independently count redds in a $1 \mathrm{~km}$ long reach of stream and comparing counts.

\section{RESULTS AND DISCUSSION}

\section{Single-pass Surveys}

The results of single-pass spawning surveys are summarized in Table 2.1. The only stream in which spawners or redds were detected was the North Fork of Anthony Creek. Two redds were found in the lower and middle sections of the stream (UTM 4085 49886, 4103 49886, USGS Anthony Butte 7.5 minute quad map). Both redds were unoccupied. The redds were $0.7 \mathrm{~m}$ long and approximately $0.5 \mathrm{~m}$ wide. This is a similar size to redds made by small resident bull trout in Silver Creek and the little Minam River. Though no redds were-detected, we observed three large $(-400 \mathrm{~mm}, 460 \mathrm{~mm}$ and $420 \mathrm{~mm}$ ) bull trout in Baldy Creek (North Fork John Day) during a distribution survey on 17 July .

\section{Multi-pass Surveys}

Spawning Timing

The timing of spawning observed in the three streams surveyed is summarized in Figure 2.1. Bull trout spawning in all streams peaked during the last two weeks in September and the first two weeks in October. Though some new redds were found in late October only one was occupied.

Redd Counts

Redd counts for each stream surveyed are summarized in Tables 2.2-2.4. The last survey on all streams except Silver Creek are incomplete. This was due to 
difficulties in conducting surveys because of snowfall in these high elevation streams.

Mill Creek had the most redds of any stream surveyed at 143 redds $(6.09 / \mathrm{km})$. This population has observed to have consistently high numbers of spawners, though this year a slight decrease was observed. Some difficulties in coordinating different survey techniques between ODFW and USFS surveyors also occurred. USFS surveyors only classed spawners into two size classes $(250-500 \mathrm{~mm}$ and $>500 \mathrm{~mm}$ ) so counts by size were less detailed.

Redd counts on Silver Creek probably underestimate true numbers because of the difficulty in identifying redds. Much of the substrate in Silver Creek is "decomposed granite" composed of a mixture of sizes ranging from coarse sand to pebbles $(-1-5 \mathrm{~mm})$. The substrate made even new redds indistinct. In addition to difficulties caused by substrate the redds were very small. Spawners observed in Silver Creek were also small. The mean estimated size $( \pm 50 \mathrm{~mm})$ of spawners observed on redds was $179 \mathrm{~mm}(n=7)$. A female mortality was recovered from Silver Creek. this mortality had a fork length of $164 \mathrm{~mm}$ and contained 3 retained eggs (0.3-0.5 mm diameter) ovaries that appeared "spawned out". From initial analysis of scales and otoliths the age of this fish was estimated at 4 years.

The little Minam River produced redd counts intermediate between Mill Creek and Silver Creek with a total of 54 redds. This may represent a slight underestimate because sections $1-5$ on the mainstem and sections 3 and 4 on Dobbin Creek were not surveyed on the last sampling pass. Substrate in the surveyed areas was a mixture ranging from pebbles to cobbles and allowed the construction of distinct, though small, redds. Spawners in the little Minam were also relatively small. The mean estimated length of fish observed on redds was $209 \mathrm{~mm}(n=38)$.

Spawning Distribution

Distribution of redds by stream reach is summarized in Figures 3.2, 3.3 and 3.4. Spawning was not evenly distributed across the entire length of stream surveyed in any of the streams. Mill Creek was the most evenly distributed with spawning observed in most sections. Bull trout redds have been observed in all Mill Creek tributaries in Figure 3.3 at some time during past surveys. This year Broken Creek was inaccessible due to a large gravel bar deposited at its mouth by spring floods.

Redd Characteristics

Redd characteristics are summarized in Table 3.5. Redds observed in streams with resident populations, Silver Creek and the Little Minam River, were roughly half the size of the redds constructed by the larger fluvial fish in Mill Creek. The mean area of redds observed in Mill Creek was significantly $(p=0.01)$ greater 
Figure 2.1 Timing of bull trout spawning in northeast Oregon.

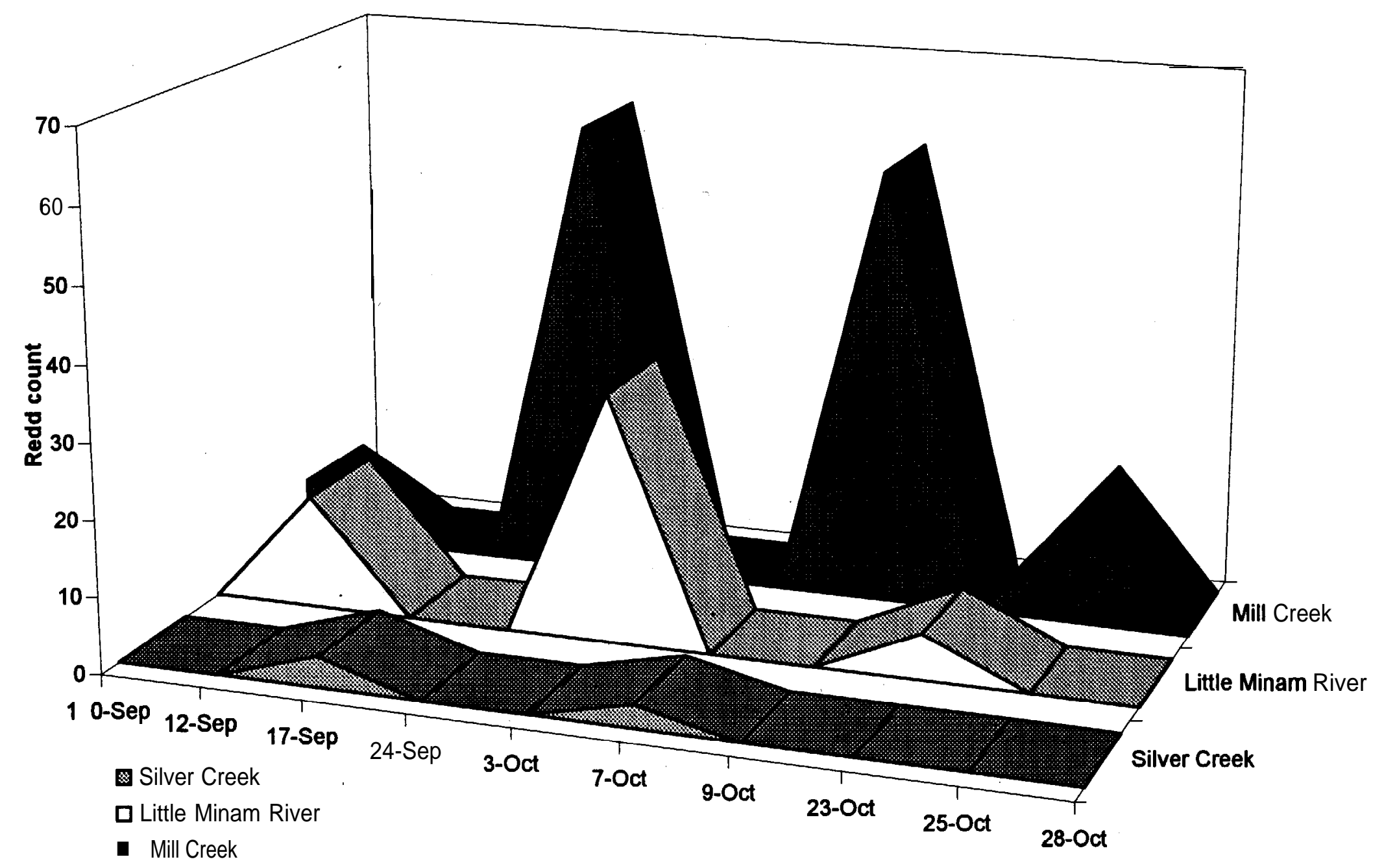


than redds in Silver Creek or the Little Minam River. There was no significant difference $(p=0.05)$ between mean redd lengths and widths reported in an early survey, length $=1.62 \mathrm{~m}$ width $=0.87$ (Martin, 1992), and those reported by our surveys. There was no significant difference detected in mean redd area between Silver Creek and Little Minam River redds $(p=0.05)$.

Most redds were widely spaced along surveyed reaches with few redds within $20 \mathrm{~m}$ of one another. Macrohabitat types in which redds were found were fairly evenly divided between riffles and pools. A few redds were found constructed in pool tail outs, though there did not appear to be a strong preference as noted by Pratt (1992).

\section{Satellite Males}

We observed satellite males on a number of occasions. All were identified as bull trout. James and Sexauer (1997) observed a number of bull trout sneak males spawning with larger fish in the Yakima River Basin. Satellite male and sneak behavior have been identified as important mechanisms used by brook trout to hybridize with bull trout (Kitano et al., 1994).

\section{Use Of Spawning Surveys For Bull Trout Population Estimates}

Our initial impression of spawning surveys is that the most accurate and useful estimate they provide is number of spawners in a population and the location of bull trout spawning habitat. However, the difficulty in detecting redds, especially in the case of resident populations, suggests that estimates would have low precision. Additionally, in some systems bull trout have been observed to spawn on alternate years (Swanberg, 1996). Spawner counts could underestimate true adult numbers due to this behavior: However, Ratliff (1992) noted an increase in redd counts in the Metolius basin after more restrictive fishing regulations were implemented. Another argument for the use of spawning surveys to track adult populations is the cryptic nature of adult bull trout. Though they occasionally occur in creel surveys, their distribution and habitat use are largely unknown. 
Table 3.1. Results of single-pass bull trout spawning surveys in northeast Oregon streams.

\begin{tabular}{|c|c|c|c|c|c|c|c|c|}
\hline \multicolumn{3}{|c|}{$\begin{array}{l}\text { Single-pass } \\
\text { surveys }\end{array}$} & \multicolumn{2}{|c|}{ Redds observed } & \multirow{2}{*}{$\begin{array}{l}\text { Bull trout } \\
\text { observed }\end{array}$} & \multicolumn{3}{|c|}{ Size Class $(\mathrm{mm})$} \\
\hline Stream & Date & $\mathrm{km}$ & Occupied & Unoccupied & & $15 c$ & 20 & 250 \\
\hline Baldy* & $\begin{array}{l}9 / 269 \\
6\end{array}$ & 4.6 & 0 & 0 & 7 & 3 & 2 & 2 \\
\hline Indian & $\begin{array}{l}9 / 26 / 9 \\
6 \\
\end{array}$ & 1.0 & 0 & 0 & 0 & & & \\
\hline $\begin{array}{l}\text { North Fk. } \\
\text { Anthony }\end{array}$ & $\begin{array}{l}9 / 25 / 9 \\
6\end{array}$ & 4.0 & 0 & 2 & 9 & 8 & 1 & \\
\hline $\begin{array}{l}\text { North Fk. } \\
\text { John Day }\end{array}$ & $\begin{array}{l}10 / 8 / 9 \\
6\end{array}$ & 13.5 & 0 & 0 & 18 & 8 & 8 & 2 \\
\hline
\end{tabular}

* Three large (>400m) bull trout observed on July 17 distribution survey. 
Table 3.2. Bull trout redd counts for the Little Minam River (Grande Ronde Basin).

\begin{tabular}{|c|c|c|c|c|c|c|c|c|}
\hline \multicolumn{3}{|c|}{ Little Minam River } & \multicolumn{2}{|c|}{ Survey Date } & \multicolumn{4}{|c|}{ 9/11-9/12 1996} \\
\hline \multirow[b]{2}{*}{ Reach } & \multicolumn{2}{|c|}{ Redds 0 bserved } & \multirow{2}{*}{$\begin{array}{l}\text { Total } \\
\text { bull trout } \\
\text { observed }\end{array}$} & \multicolumn{5}{|c|}{ Size class $(\mathrm{mm})$} \\
\hline & Occupied & Unoccupied & & 150 & 200 & $25 c$ & 300 & $>300$ \\
\hline 1 & 0 & 0 & 6 & 6 & & & | & \\
\hline 2 & 1 & 0 & 8 & & 2 & & & \\
\hline 3 & 0 & 1 & 0 & & & & & \\
\hline 4 & 1 & 1 & 1 & & & & 1 & \\
\hline 5 & 0 & 0 & 5 & & & & & \\
\hline 6 & $4^{\star}$ & 0 & 10 & 1 & 7 & 1 & 1 & \\
\hline 7 & $3^{\star}$ & 0 & 11 & 2 & 7 & 2 & & \\
\hline \multicolumn{9}{|c|}{ Dobbin Creek } \\
\hline 1 & 2 & 2 & 9 & & 9 & & & \\
\hline 2 & 0 & 0 & 0 & & & & & \\
\hline 3 & 0 & 0 & 0 & & & & & \\
\hline 4 & 0 & 0 & 0 & & & & & \\
\hline Total & 11 & 4 & 50 & 9 & 25 & 3 & 2 & 0 \\
\hline
\end{tabular}

${ }^{*}$ Active redd building observed

\begin{tabular}{|c|c|c|c|c|c|c|c|c|}
\hline \multicolumn{3}{|c|}{ Little Minam River } & \multicolumn{2}{|c|}{ Survey Date } & \multicolumn{4}{|c|}{ 10/2-10/3 1996} \\
\hline & \multicolumn{2}{|c|}{ Redds Observed } & Total & \multicolumn{5}{|c|}{ Size class (mm) } \\
\hline Reach & Occupied & Unoccupled & $\begin{array}{l}\text { bull trout } \\
\text { observed }\end{array}$ & 150 & 200 & 250 & 300 & $>300$ \\
\hline 1 & 0 & 0 & 2 & & 2 & & & \\
\hline 2 & 1 & 4 & 7 & $\overline{1}$ & 5 & 1 & & \\
\hline 3 & 2 & 1 & 3 & 3 & & & & \\
\hline 4 & 0 & 2 & 3 & 3 & & & & \\
\hline 5 & 1 & 2 & 6 & $\overline{3}$ & 3 & & & \\
\hline 6 & 3 & 3 & 9 & & 9 & & & \\
\hline 7 & 5 & 6 & 6 & & 4 & 2 & & \\
\hline \multicolumn{9}{|c|}{ Dobbin Creek } \\
\hline 1 & 1 & 2 & & & 1 & & & \\
\hline 2 & 0 & 0 & 1 & 1 & & & & \\
\hline 3 & 0 & 0 & 1 & 1 & & & & \\
\hline 4 & 0 & 0 & 1 & 1 & & & & \\
\hline Total & 13 & 20 & 39 & 13 & 24 & 3 & 0 & 0 \\
\hline
\end{tabular}


Table 3.2. Bull trout redd counts for the Little Minam River (Grande Ronde Basin)continued.

\begin{tabular}{|c|c|c|c|c|c|c|c|c|}
\hline \multicolumn{3}{|c|}{\begin{tabular}{|l} 
Little Minam River \\
\end{tabular}} & \multicolumn{2}{|c|}{ Survey Date } & \multicolumn{4}{|c|}{$10 / 231996$} \\
\hline \multirow{2}{*}{ Reach } & \multirow{2}{*}{$\begin{array}{l}\text { Redds } \\
\text { Occupied }\end{array}$} & \multirow{2}{*}{$\begin{array}{l}\text { Observed } \\
\text { Unoccupied }\end{array}$} & \multirow{2}{*}{$\begin{array}{l}\text { Total } \\
\text { bull trout } \\
\text { bobserved }\end{array}$} & \multicolumn{5}{|c|}{ Size class $(\mathrm{mm})$} \\
\hline & & & & 150 & 200 & 250 & 300 & $>300$ \\
\hline 1 & & & 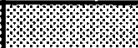 & & & & & \\
\hline 2 & Nor: & SWundeyed & TI & & & & & \\
\hline 3 & "थ:-2: & U. & $\sqrt{1=2:=2=2}=$ & & & & & \\
\hline 4 & (য়: & $U_{n}$ & $\int_{i=8.8}$ & & & & & \\
\hline \multicolumn{6}{|c|}{ 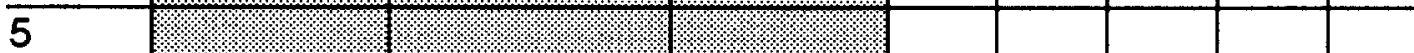 } & & & \\
\hline 6 & 0 & 0 & 8 & & 8 & & & \\
\hline 7 & 0 & 0 & 0 & & & & & \\
\hline \multicolumn{9}{|c|}{ Dobbin Creek } \\
\hline 1 & 1 & 4 & 1 & & & 1 & & \\
\hline 2 & 0 & 1 & 0 & & & & & \\
\hline 3 & Nos & Surveyed & & & & & & \\
\hline 4 & W"1. & "In: & T:12: & & & & & \\
\hline Total & 1 & 5 & 1 & & & 1 & & \\
\hline $\begin{array}{l}\text { Year } \\
\text { Total }\end{array}$ & 25 & 29 & 98 & 22 & 57 & 7 & 2 & 0 \\
\hline \multicolumn{2}{|c|}{$\begin{array}{ll}\text { Total } & 54 \\
\text { count. } & \end{array}$} & \multirow[b]{2}{*}{$\mid \begin{array}{l}\text { Redds/km } \\
\text { L Minam }\end{array}$} & \multirow[b]{2}{*}{3.6} & \multirow{2}{*}{\multicolumn{4}{|c|}{$\begin{array}{l}\text { Redds/km } 0.5 \\
\text { Dobbin }\end{array}$}} & \\
\hline $\begin{array}{l}\text { Redds } \\
\mathrm{m} \text { tota }\end{array}$ & 3.2 & & & & & & & \\
\hline
\end{tabular}


Table 3.3. Mill Creek (Walla Walla Basin) bull trout redd counts.

\begin{tabular}{|c|c|c|c|c|c|c|c|c|c|}
\hline \multirow{2}{*}{$\begin{array}{l}\text { Mill Cr. } \\
\text { Reach }\end{array}$} & \multicolumn{2}{|c|}{ Redds observed } & \multirow{2}{*}{$\begin{array}{l}9 / 5-9 / 10 \\
\text { Total bull trout obe. }\end{array}$} & \multicolumn{6}{|c|}{ Size Class $(\mathrm{mm})$} \\
\hline & $\begin{array}{l}\text { Occupie } \\
A\end{array}$ & Unoccupied & & 100 & 200 & 300 & 400 & 500 & $>500$ \\
\hline 1 & 0 & 0 & 0 & & & & & & \\
\hline 2 & 0 & 0 & 0 & & & & & & \\
\hline 3 & 0 & 0 & 0 & & & & & & \\
\hline 4 & 1 & 2 & 1 & & & & 1 & & \\
\hline 5 & 3 & 0 & 5 & & & 3 & 2 & & \\
\hline 6 & 1 & 0 & 1 & & & & 1 & & \\
\hline 7 & 0 & 0 & 0 & & & & & & \\
\hline Total & 5 & 2 & 7 & & & 3 & 4 & & \\
\hline Low & 0 & 0 & 0 & & & & & & \\
\hline Broken & 0 & 0 & 0 & & & & & & \\
\hline Paradise & 0 & 0 & 0 & & & & & & \\
\hline N Fork & 0 & 1 & 0 & & & & & & \\
\hline Deadman & 0 & 0 & 0 & & & & & & \\
\hline Burnt Fk & 0 & 0 & 0 & & & & & & \\
\hline Green & 0 & 0 & 0 & & & & & & \\
\hline Bull & 0 & 0 & 0 & & & & & & \\
\hline Total & 5 & 3 & 7 & & & 3 & 4 & & \\
\hline & & & & & & & & & \\
\hline Mill Cr. & \multicolumn{2}{|c|}{ Redds observed } & $9 / 23-9 / 24$ & \multicolumn{6}{|c|}{ Size Class $(\mathrm{mm})$} \\
\hline Reach & $\begin{array}{l}\text { Occupie } \\
d\end{array}$ & Unoccupied & Total bull trout obs. & 100 & 200 & 300 & 400 & 500 & $>500$ \\
\hline 1 & 0 & 0 & 10 & & & & & & \\
\hline 2 & 0 & 0 & 0 & & & & & & \\
\hline 3 & 0 & 0 & 0 & & & & & & \\
\hline 4 & 4 & 9 & 11 & & & & & & 1 \\
\hline 5 & 4 & 37 & 21 & & & & & & 2 \\
\hline 6 & 1 & 1 & 1 & & & & & & \\
\hline 7 & 0 & 2 & 0 & & & & & & \\
\hline Total & 9 & 49 & 43 & & & & & & 2 \\
\hline Low & 0 & 0 & 0 & & & & & & \\
\hline Broken & 0 & 0 & 0 & & & & & & \\
\hline Paradise & 1 & 2 & 1 & & 1 & & & & \\
\hline N Fork & 0 & 0 & 2 & 1 & 1 & & & & \\
\hline Deadman & 0 & 0 & 0 & & & & & & \\
\hline Burnt Fk & 0 & 0 & 0 & 1 & 1 & & & & \\
\hline Green(9) & 0 & 0 & 0 & & & & & & \\
\hline Bull & 0 & 0 & 0 & & & & & & \\
\hline Total & 10 & 51. & 46 & 2 & 3 & & & & 2 \\
\hline
\end{tabular}


Table 3.3. Mill Creek (Walla Walla basin) bull trout redd counts continued.

\begin{tabular}{|c|c|c|c|c|c|c|c|c|c|}
\hline & \multicolumn{2}{|c|}{ Redds observed } & $10 / 2-$ & \multicolumn{6}{|c|}{ Size Class (mm) } \\
\hline Reach & Occupied & Unoccupied & \begin{tabular}{|l} 
Total bull \\
trout obs.
\end{tabular} & & 200 & 300 & 400 & 500 & $>500$ \\
\hline 1 & 0 & 1 & 10 & & & & & & \\
\hline 2 & 0 & 0 & 0 & & & & & & \\
\hline 3 & 0 & 0 & 0 & & & & & & \\
\hline 4 & 0 & 3 & 2 & & & & & 1 & 1 \\
\hline 5 & 0 & 2 & 0 & & & & & & \\
\hline 6 & 0 & 6 & 0 & & & & & & \\
\hline 7 & 0 & 0 & 0 & & & & & & \\
\hline Total & 0 & 12 & ${ }^{4} \pi$ & & & & & $\hat{\imath}$ & $\hat{\imath}$ \\
\hline Low & 0 & 18 & 0 & & & & & & \\
\hline Broken & 0 & 0 & 0 & & & & & & \\
\hline Paradise & $\overline{1}$ & $\overline{7}$ & 0 & & & & & & \\
\hline N Fork & 0 & 5 & 0 & & & & & & \\
\hline Deadman & 0 & 3 & 0 & & & & & & \\
\hline Burnt.5k & n & 12 & $n$ & & & & & & \\
\hline Green & 0 & 0 & 0 & & & & & & \\
\hline Bull & 0 & 0 & 0 & & & & & & \\
\hline Total & 1 & 57 & 12 & & & & & & \\
\hline
\end{tabular}


Table 3.3. Mill Creek (Walla Walla Basin) bull trout redd counts continued.

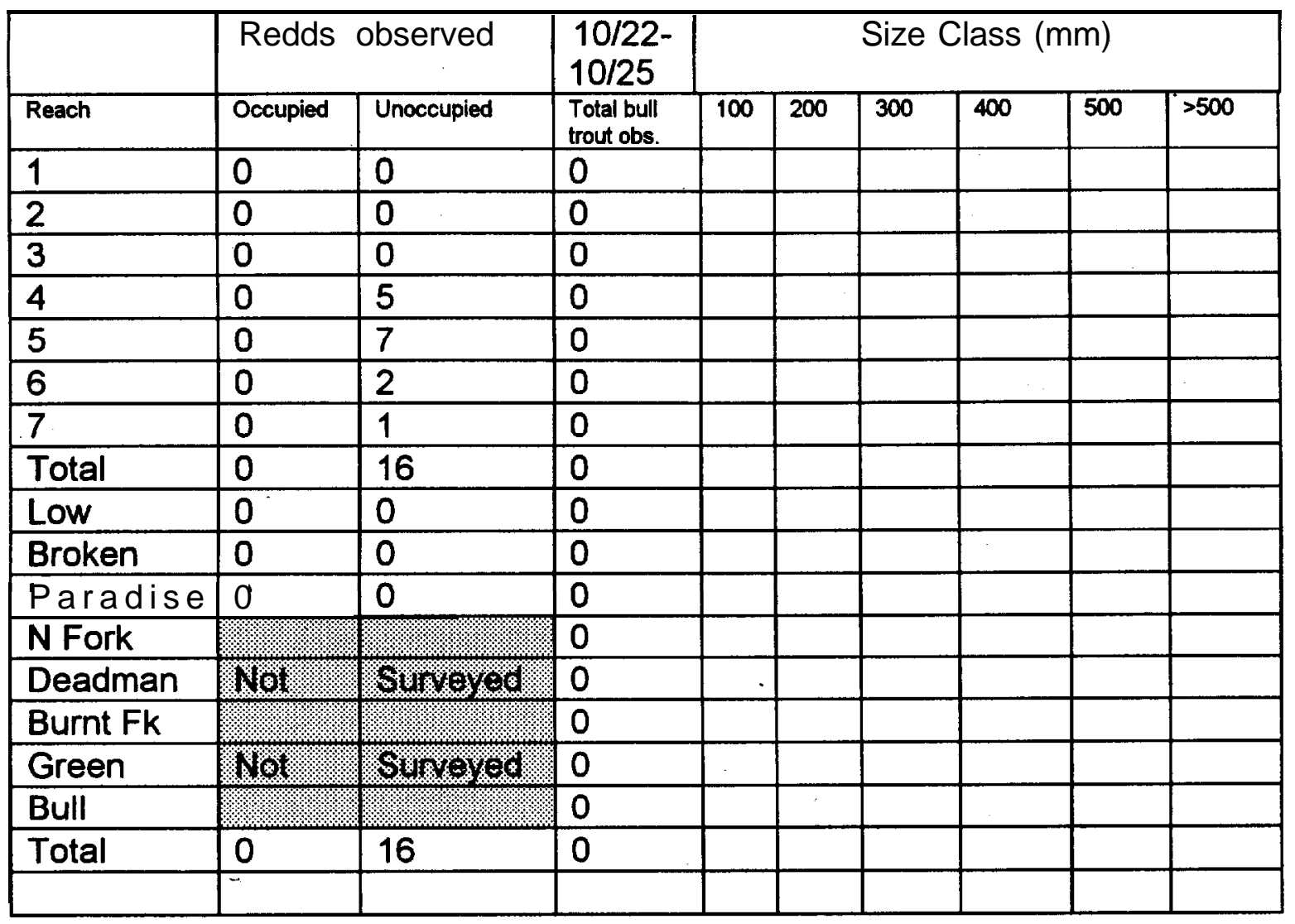

\begin{tabular}{|lllll|}
\hline & Occupied & Unoccupied & All Redds & Redds $/ \mathrm{km}$ \\
\hline 1996 & & & & \\
Total & 16 & 127 & 143 & 6.09 \\
\hline
\end{tabular}


Table 3.4. Silver Creek (Powder River Basin) bull trout redd counts.

\begin{tabular}{|c|c|c|c|c|c|c|c|c|c|}
\hline \multicolumn{3}{|c|}{ Silver Greek } & \begin{tabular}{|l} 
Survey Date \\
\end{tabular} & \multicolumn{6}{|c|}{$9 / 12-9 / 171996$} \\
\hline & \multicolumn{2}{|c|}{ Redds Observed } & Total & \multicolumn{6}{|c|}{ Size class $(\mathrm{mm})$} \\
\hline Reach & Occupied & Unoccupied & bull trout observed & 100 & 150 & 200 & 250 & 300 & $>300$ \\
\hline 1 & 0 & 0 & 4 & & 4 & & & & \\
\hline 2 & 0 & 0 & 2 & & & 2 & & & \\
\hline 3 & 0 & 1 & 0 & & & & & & \\
\hline 4 & 0 & 0 & 17 & & 4 & 8 & & & \\
\hline 5 & 3 & 0 & 6 & & 1 & 4 & & & \\
\hline 6 & 0 & 0 & 2 & 2 & & & & & \\
\hline 7 & 0 & 0 & 3 & 3 & & & & & \\
\hline Total & 3 & 1 & 30 & 5 & 9 & 14 & 0 & 0 & 0 \\
\hline
\end{tabular}

\begin{tabular}{|c|c|c|c|c|c|c|c|c|c|}
\hline \multicolumn{3}{|c|}{ Silver (; $\overline{\text { reek }}$} & \multirow{2}{*}{$\begin{array}{l}\text { Survey Date } \\
\text { Total } \\
\end{array}$} & & \multicolumn{5}{|c|}{$10 / 71996$} \\
\hline \multirow{2}{*}{ Reach } & \multicolumn{2}{|c|}{ Redds Observed } & & \multicolumn{6}{|c|}{ Size class (mm) } \\
\hline & Occupied & Unoccupied & bull trout observed & 100 & 150 & 200 & 250 & 300 & $>300$ \\
\hline 1 & 1 & 0 & 5 & 3 & 2 & & & & \\
\hline 2 & 0 & 0 & 0 & & & & & & \\
\hline 3 & 0 & 0 & 4 & & 1 & 3 & & & \\
\hline 4 & 0 & 0 & 0 & & & & & & \\
\hline 5 & 1 & 1 & 14 & 5 & $\overline{4}$ & 6 & & & \\
\hline 6 & 0 & 0 & 0 & & & & & & \\
\hline 7 & 0 & 0 & 0 & & & & & & \\
\hline Total & 2 & 1 & 23 & 8 & 7 & 9 & 0 & 0 & 0 \\
\hline
\end{tabular}

\begin{tabular}{|c|c|c|c|c|c|c|c|c|c|}
\hline \multicolumn{3}{|l|}{\begin{tabular}{|l} 
Silver Creek \\
\end{tabular}} & \multicolumn{2}{|l|}{ Survev Date } & \multicolumn{5}{|c|}{$10 / 26-10 / 281996$} \\
\hline & Redds & Observed & Total & Siz & clas & $(\mathrm{mn}$ & & & \\
\hline Reach & Occupied & Unoccupied & bull trout observed & 100 & 150 & 2001 & 250 & 300 & $>300$ \\
\hline$!$ & $\underline{0}$ & 0 & $!$ & & & 1 & & & \\
\hline 2 & 0 & 0 & 8 & & & 8 & & & \\
\hline 3 & 0 & 0 & 0 & & & & & & \\
\hline 4 & 0 & 0 & 0 & & & & & & \\
\hline 5 & 0 & 0 & 0 & & & & & & \\
\hline 6 & 0 & 0 & 0 & & & & & & \\
\hline 7 & 0 & 0 & 1 & & & 1 & & & \\
\hline Total & 0 & 0 & 10 & & & 10 & & & \\
\hline & & & & & & & & & \\
\hline Year total & 5 & 2 & 63 & 13 & 16 & 33 & 0 & 0 & 0 \\
\hline Redds/km & 0.8 & & & & & & & & \\
\hline
\end{tabular}




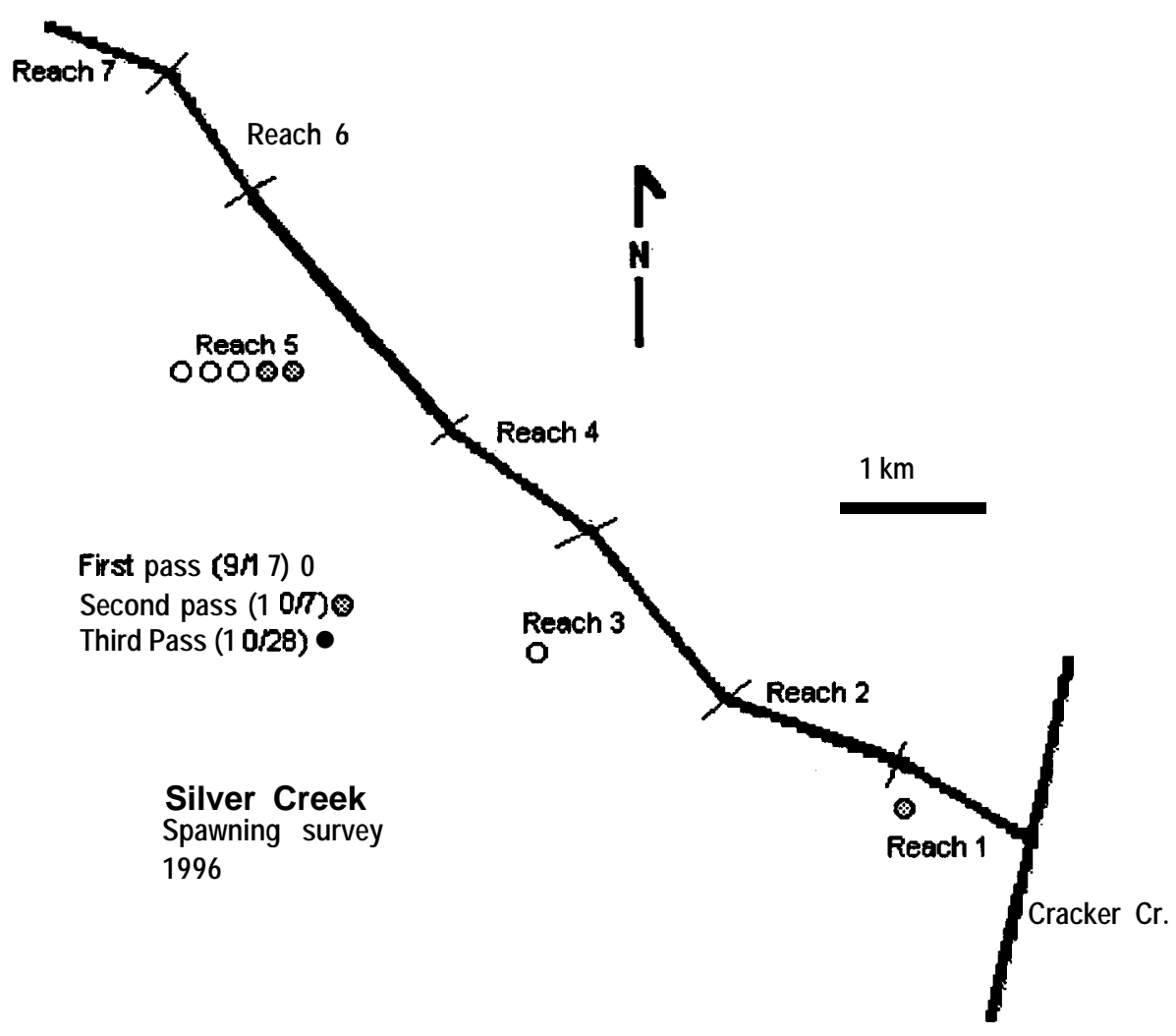

Figure 3.2. Bull trout redd distribution in Silver Creek (Powder Basin). 


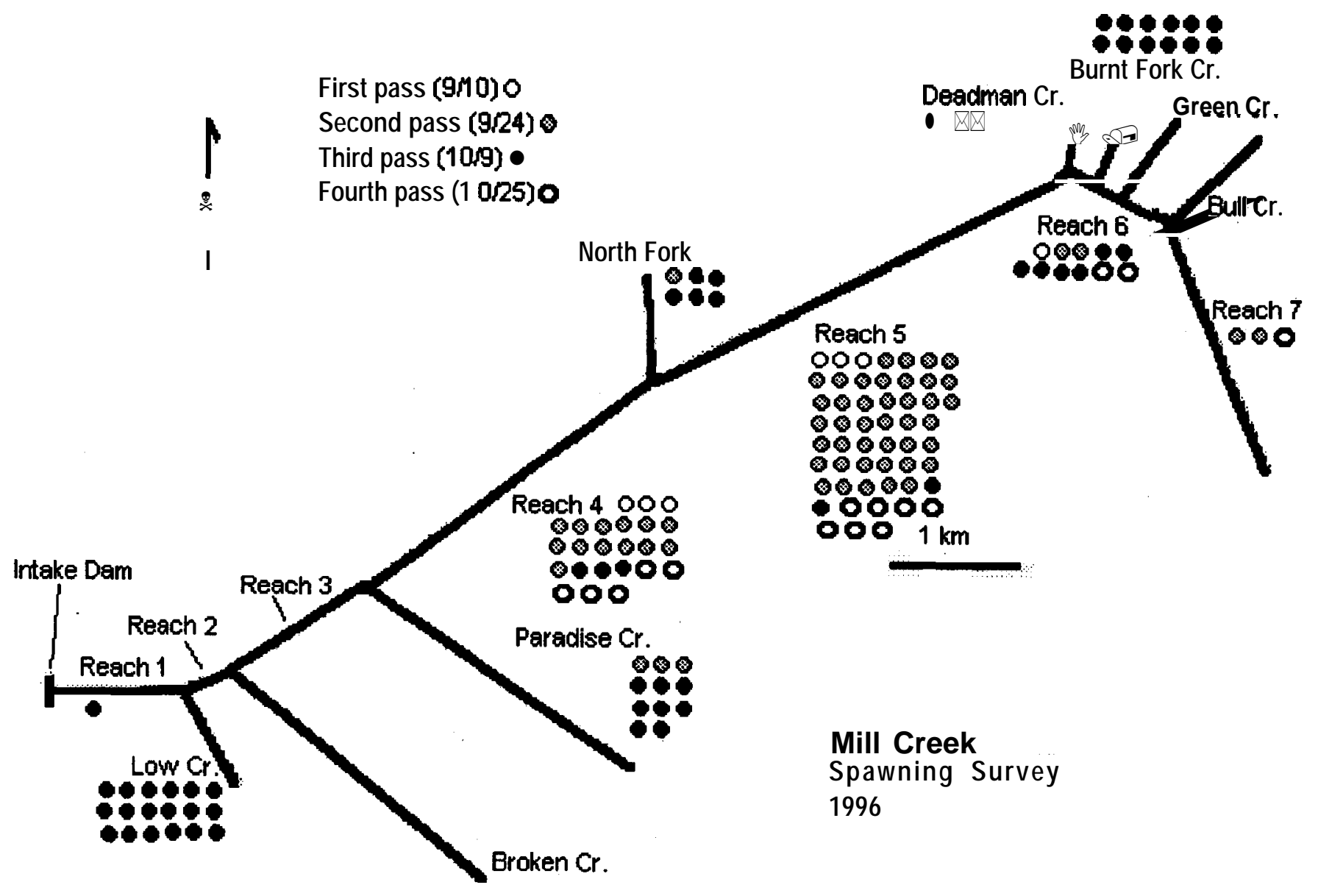

Figure 3.3. Spawning distribution in Mill Creek (Walla Walla Drainage). 


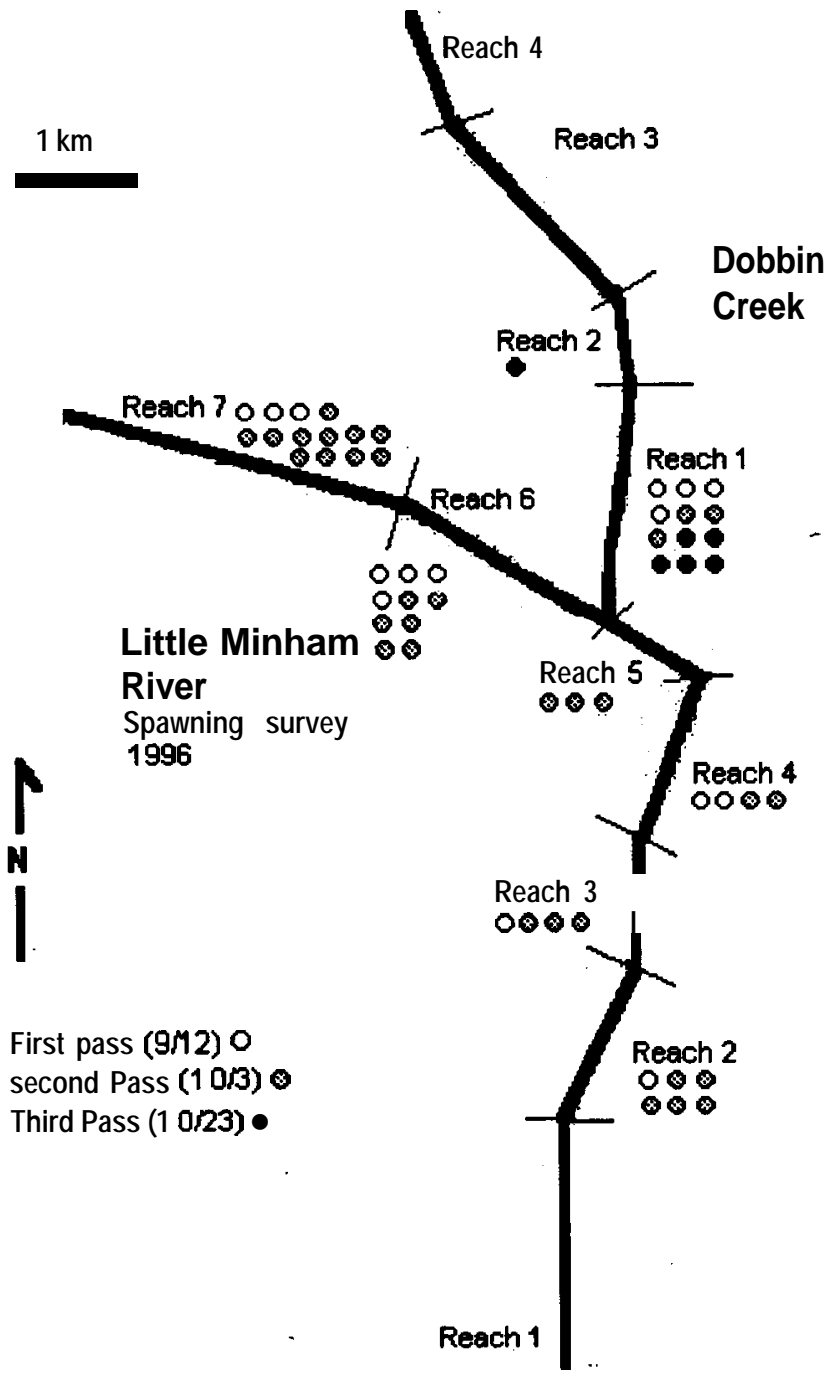

Figure 3.4. Bull trout redd distribution in the Little Minam River (Grande Ronde Basin). 
Table 3.5. Bull trout redd characteristics.

\begin{tabular}{|c|c|c|c|c|c|c|c|c|c|c|c|}
\hline Stream & $n$ & & length(m) & width $(m)$ & $\begin{array}{l}\text { n) pocket } \\
\text { depth }(m)\end{array}$ & $\begin{array}{l}\text { water } \\
\text { depth }(m)\end{array}$ & $\begin{array}{l}\text { mean } \\
\text { pebble } \\
\text { diam } \\
\text { (cm) }\end{array}$ & $\begin{array}{l}\text { sand } \\
\text { and } \\
\text { silt \% }\end{array}$ & $\operatorname{area}(m 2) t$ & temperature $(\mathrm{C})$ & $\begin{array}{l}\text { LengthIWidth } \\
\text { ratio }\end{array}$ \\
\hline $\begin{array}{l}\text { Silver Creek } \\
\text { (resident population) }\end{array}$ & 6 & $\begin{array}{l}\text { mean } \\
\text { sd } \\
\max \\
\min \end{array}$ & $\begin{array}{l}0.83 \\
0.30 \\
1.40 \\
0.60\end{array}$ & $\begin{array}{l}0.33 \\
0.08 \\
0.45 \\
0.25\end{array}$ & $\begin{array}{l}0.04 \\
0.02 \\
0.07 \\
0.02\end{array}$ & $\begin{array}{l}0.20 \\
0.04 \\
0.24 \\
0.12\end{array}$ & $\begin{array}{l}1.35 \\
0.10 \\
1.40 \\
1.20\end{array}$ & $\begin{array}{r}27.67 \\
35.36 \\
90.00 \\
0.00\end{array}$ & $\begin{array}{l}0.28 \\
0.14 \\
0.56 \\
0.15\end{array}$ & $\begin{array}{l}6.50 \\
1.22 \\
8.00 \\
5.00\end{array}$ & $\begin{array}{l}2.51 \\
0.70 \\
3.50 \\
1.33\end{array}$ \\
\hline $\begin{array}{l}\text { Mill Creek } \\
\text { (fluvial population) }\end{array}$ & 22 & \begin{tabular}{|l|} 
mean \\
sd \\
$\max$ \\
$\min$
\end{tabular} & $\begin{array}{l}1.27 \\
0.59 \\
2.50 \\
0.40\end{array}$ & $\begin{array}{l}0.67 \\
0.54 \\
3.00 \\
0.23 \\
\end{array}$ & $\begin{array}{l}0.04 \\
0.04 \\
0.12 \\
0.00\end{array}$ & $\begin{array}{l}0.26 \\
0.10 \\
0.50 \\
0.05\end{array}$ & $\begin{array}{l}1.99 \\
0.79 \\
3.60 \\
0.85 \\
\end{array}$ & $\begin{array}{r}3.67 \\
4.51 \\
14.00 \\
0.00 \\
\end{array}$ & $\begin{array}{l}0.86 \\
0.63 \\
2.40 \\
0.11 \\
\end{array}$ & $\begin{array}{r}7.57 \\
0.84 \\
10.00 \\
7.00 \\
\end{array}$ & $\begin{array}{l}2.20 \\
0.69 \\
3.33 \\
0.23\end{array}$ \\
\hline $\begin{array}{l}\text { Silver Creek } \\
\text { (resident populatio }\end{array}$ & $\begin{array}{l}\text { pool } \\
n \text { ) } \\
\text { rapid }\end{array}$ & 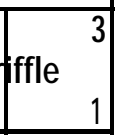 & 2 & \begin{tabular}{l|l}
2 & $\mathrm{C}$ \\
2 & $\mathrm{r}$
\end{tabular} & $\begin{array}{l}\text { count } \\
\text { mean dista }\end{array}$ & ance (m) & & & & & \\
\hline $\begin{array}{l}\text { Little Minam River } \\
\text { (resident population) }\end{array}$ & $\begin{array}{l}\text { pool } \\
\text { riffle } \\
\text { rapid } \\
\text { glide }\end{array}$ & $\begin{array}{r}20 \\
24 \\
9 \\
1 \\
\end{array}$ & 4 & \begin{tabular}{r|r}
14 & $\mathrm{C}$ \\
4.93 & $\mathrm{n}$
\end{tabular} & $\begin{array}{l}\text { count } \\
\text { mean dista }\end{array}$ & ance (m) & & & & & \\
\hline $\begin{array}{l}\text { Mill Creek } \\
\text { (fluvial population) }\end{array}$ & $\begin{array}{l}\text { pool } \\
\text { riffle }\end{array}$ & $\begin{array}{r}18 \\
5 \\
\end{array}$ & 1 & \begin{tabular}{r|}
2 \\
1.5 \\
\end{tabular} & \multicolumn{7}{|c|}{$\begin{array}{l}\text { count } \\
\text { mean distance }(m)\end{array}$} \\
\hline
\end{tabular}




\section{SECTION 4 \\ SUMMARY AND ANALYSIS OF HISTORICAL JUVENILE BULL TROUT DOWNSTREAM MIGRANT TRAP CATCHES IN THE GRANDE RONDE BASIN.}

\section{Introduction}

The Grand Ronde River originates in the Blue and Wallowa mountain ranges of northeast Oregon. It flows north for approximately $241 \mathrm{~km}$ before joining the Snake River in the state of Washington. Much of the drainage is high elevation forest. However, many streams in this basin have suffered significant impacts from logging, agriculture and mining.

Historically, this basin supported large runs of spring and fall chinook, coho, sockeye salmon and steelhead. Bull trout were probably widely distributed in the basin and may have also used the Snake River (Buchanan et al. 1996). The only remaining anadromous populations are spring chinook and steelhead that are present in greatly depressed numbers. At present, bull trout inhabit the upper reaches of 18 headwater streams in the Grande Ronde Drainage. This primarily represents rearing and spawning habitat. Adults have been recorded in creel census in the mainstem Grande Ronde and Wallowa Rivers but their movements and habitat use are largely unknown: The movements of juvenile bull trout after they leave their natal streams are totally unknown.

The anadromous salmonid populations of the Grande Ronde River have been the subject of study since the 1960's. The data that we are reviewing begins with an ODFW study conducted on Lookingglass Creek from 196570 (Wayne Burke, unpublished data). In 1993 four rotary screwtraps were emplaced in the basin to study downstream migration of chinook and steelhead smolts. Traps were emplaced at: Lookingglass Creek (Confederated Tribes of the Umatilla Indian reservation), on the Mainstem Grande Ronde River near the town of Elgin at river km 164 (ODFW), on Catherine Creek above the town of Union at river km 32 (ODFW), and on the upper Grande Ronde above Fly Creek at river km 299 (ODFW). In 1994 another screw trap was placed in the lower Grande Ronde near river km 43 . In 1996 two more screw traps, one in the lower Lostine River at river km 3 and one in the lower Wallowa River were emplaced. In 1997 an additional screw trap will be emplaced on the upper Wallowa River. A Figure 4.1 illustrates a schematic map of trap locations.

The high level of monitoring in the Grande Ronde River has produced incidental bull trout catch data. This data provides valuable information on the movements and life history of bull trout in the Grande Ronde Basin. Additionally, 
trapping operations on Lookingglass Creek allow a comparison of data sets separated by 22 years.

We have focused on juvenile bull trout, fork length $<300 \mathrm{~mm}$, in this analysis. This fork length was chosen because most studies have noted that bull trout reach sexual maturity at no younger than 4 years (Pratt, 1992; USFS 1989). In most migrant populations bull trout less than $300 \mathrm{~mm}$ are less than 4 years old (Pratt, 1992; USFS 1989).

\section{Methods}

. Data from the 19651970 Lookingglass studies were collected using a weir/diversion type trap. It was located near the present site of Lookingglass Fish Hatchery (ODFW). Data from the 1990's were collected using 1.5 meter and 2.4 meter rotary screw traps. Locations of the rotary screw traps are illustrated in Figure 4.1 .

Catch data was compiled using a PC with Excel and Dbase software. Length frequencies were plotted and a rough estimate of age groups made using the Peterson Method. Mean lengths of catches from different locations or times were tested for significant differences with t-tests and analysis of variance $(P=0.05)$ using Sigma-stat software.

\section{Results and Discussion}

\section{Length Frequencies}

Lookinglass Creek

Length frequencies of bull trout captured in Lookingglass Creek from 196571 and from 1993-96 are summarized in Figure 4.2. Lookingglass Creek juvenile $(<300 \mathrm{~mm}$ ) bull trout in the spring emigration (February-July) were significantly smaller (mean fork length $166 \mathrm{~mm}$ ) than juvenile bull trout in the fall run (AugustJanuary). This is true for both 1965-71 and 1993-96 data sets. Mean lengths for both runs are listed in Table 4.1. Bull trout captured during the spring and fall runs are compared in Figures 4.3. Comparison of the two Lookingglass data sets revealed that the mean fork length of juvenile emigrants in 1965-71 $(213 \mathrm{~mm})$ was significantly $(P=0.05)$ greater than the mean fork length of 1993-I 996 juvenile emigrants $(193.3 \mathrm{~mm})$. Mean fork lengths of spring and fall runs for 1965-71 data are both significantly greater than 1993-I 996 data.

Interpretation of length frequencies into age classes is somewhat unclear for Lookingglass Creek data. During the February-August migration period the majority of fish captured are 100-200 mm long ('93-96=80.3\%, '65-71=68.1\%). The next largest group consists of fish $200-280 \mathrm{~mm}$ long ('93-96=13.7\%, 65-71=30.3\%). The 
smallest group consisted of fish 20-100 mm long ('93-96=6.0\%, '65-71 $=1.6 \%$ ). These three groups appear to be O-I year old fish $(20-100 \mathrm{~mm}), 2-3$ year old fish $(100-200 \mathrm{~mm})$ and $3-4$ year old fish $(<200 \mathrm{~mm})$. These estimates agree fairly well with other length age studies conducted on bull trout in Oregon (USFS, 1989). Scales were collected from bull trout in the 1993-96 data set. Analysis of these scales has not been completed, but will provide greater detail and a validation of these length frequency based estimates.'

The September-January migration period catches were dominated by fish larger than $200 \mathrm{~mm}(93-96=63.62 \%, 65-71=63.6 \%)$ followed by $100-200 \mathrm{~mm}$ fish ('93-96=35.58\%, '65-71 =13.34\%) and $20-\mathrm{I} 00 \mathrm{~mm}$ fish ('93-96=0.8\%, '65-71=0\%). It is unclear if these fish are migrating downstream for the first time or if they are returning after an upstream migration.

Table 4.1. Length frequencies (fork length) of.juvenile $(>300 \mathrm{~mm}$ ) bull trout emigrants captured at Lookingglass Creek during spring and fall downstream migrations.

\begin{tabular}{|l|l|l|l|l|l|l|}
\hline & \multicolumn{3}{|c|}{ Lookingglass 1965-I 971 } & \multicolumn{3}{|c|}{ Lookingglass 1993-I 996 } \\
\hline Run & Meaqhm) & $\begin{array}{l}\text { Standard } \\
\text { Deviation }\end{array}$ & $\mathbf{n}$ & $\begin{array}{l}\text { Mean } \\
\text { FL }(\mathrm{mm})\end{array}$ & $\begin{array}{l}\text { Standard } \\
\text { Deviation }\end{array}$ & $\mathbf{n}$ \\
\hline Spring & $179.2^{\text {ab }}$ & $\mathbf{4 0 . 6}$ & 118 & $165.7^{\prime \prime}$ & 35.3 & 68 \\
\hline Fall & $230.6^{\text {bc }}$ & 39.4 & 233 & $209.3^{\prime \prime}$ & 43.4 & 118 \\
\hline All & $213.0^{\text {d }}$ & 46.33 & 349 & $193.3^{\text {d }}$ & 145.7 & 186 \\
\hline
\end{tabular}

Means bearing the same letter are significantly different $(p=0.05)$

Grande Ronde River

Mean fork lengths of juvenile bull trout captured at various trap sites are summarized in Table 4.2 The Elgin trap site had the largest mean fork length (260 $\mathrm{mm}$ ). This is probably because this trap is located in the Grande Ronde and catches are mainly older bull trout moving along the mainstem. However, the trap is located near the mouth of Indian Creek and may intercept emigrants from that stream. The Lostine River trap was not compared with other sites because it began fishing in November 1996, so catches may be biased towards older fish. The pattern of a spring run composed mainly of 2-3 year old fish and a fall run with a large component of 3-4 year old fish observed in Lookingglass creek appears to also occur in other parts of the Grand Ronde Basin. 
Figure 4.1. A schematic map of fish traps operated in the Grande Ronde Basin.

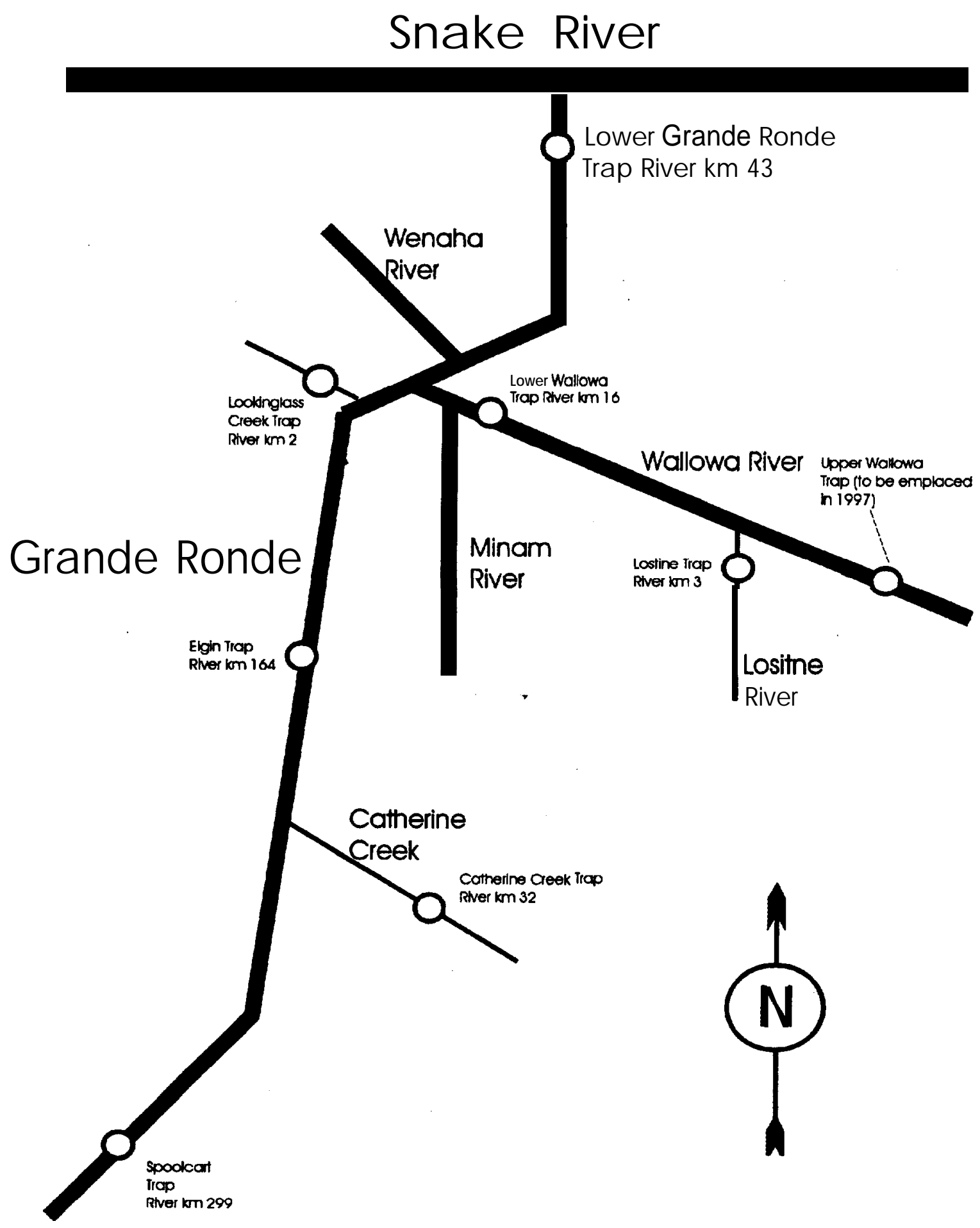


Figure 4.2. Length frequencies of bull trout captured at Lookinglass Creek 1965-I 971 and 19931996.

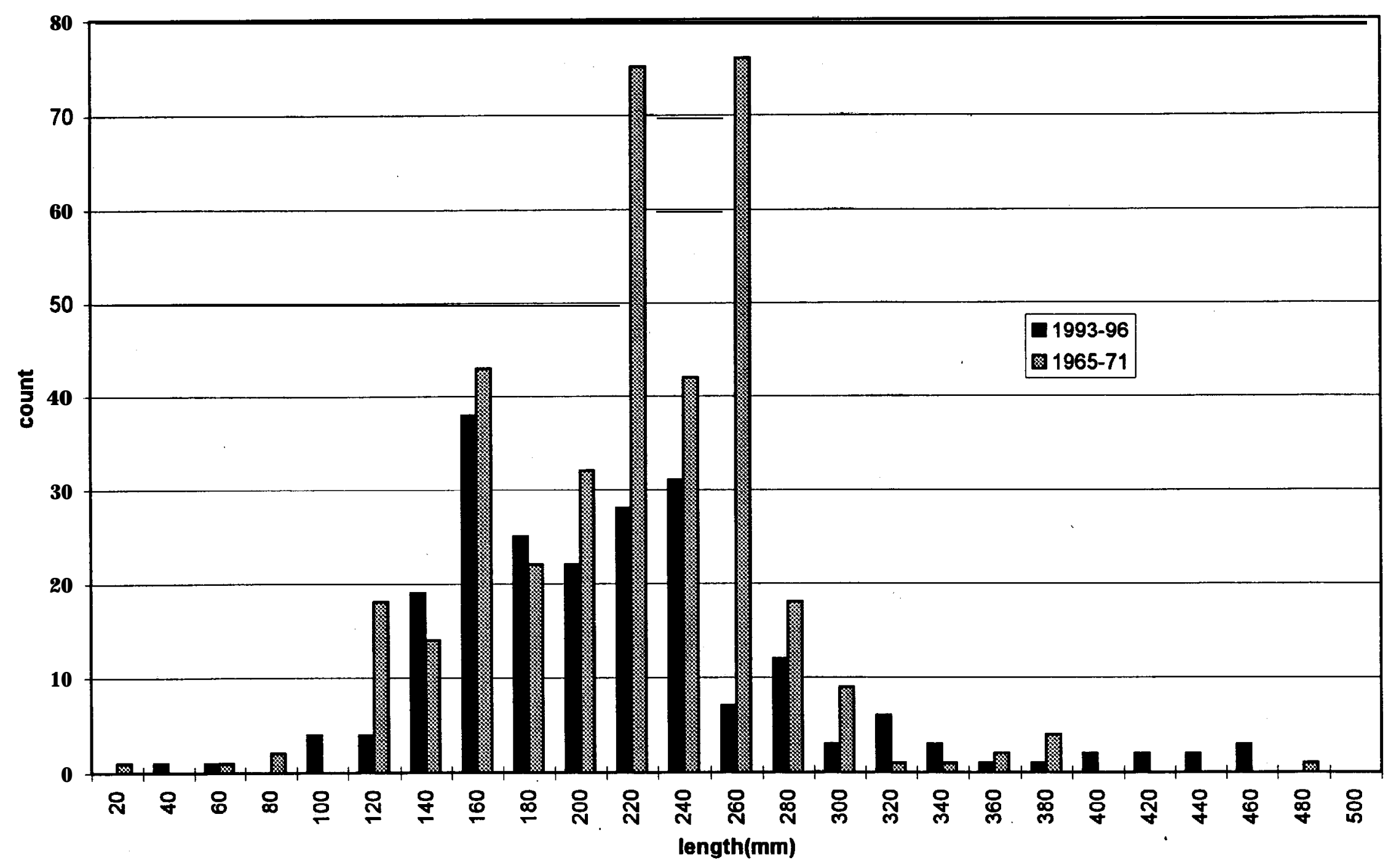


Figure 4.3. Comparison of spring (February-August) and fall (September-January) runs of . juvenile bull trout from Lookingglass Creek.

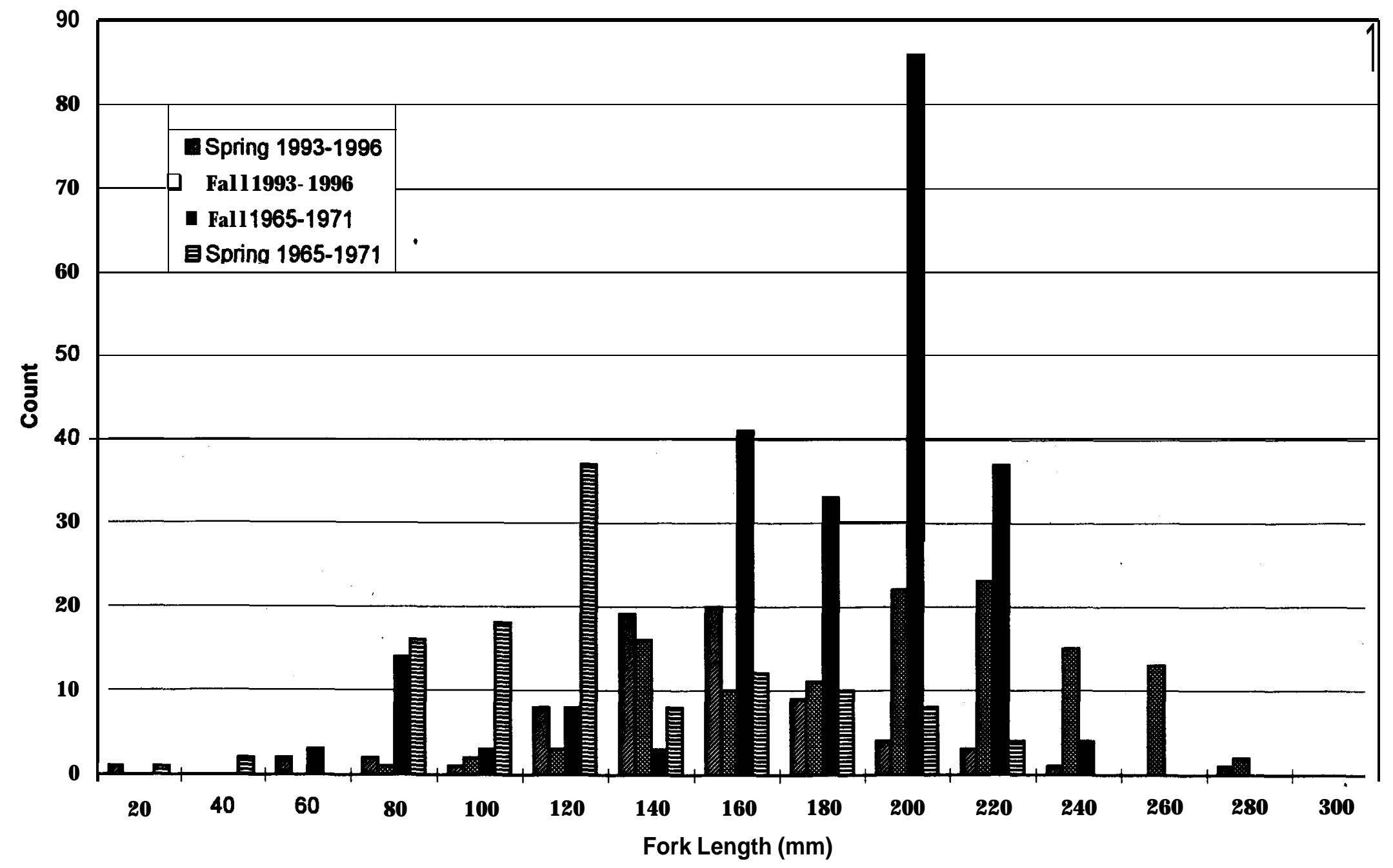


Table 4.2. Comparison of mean fork lengths of bull trout caught at screw traps in the Grande Ronde Basin

\begin{tabular}{|l|r|r|r|r|r|}
\hline & $\begin{array}{l}\text { Lookingglass L Lok ingolass } \\
\text { 6471 }\end{array}$ & $\begin{array}{l}\text { Catherine } \\
\text { creek 9496 }\end{array}$ & $\begin{array}{l}\text { lelgin 93-96 } \\
\text { (mainstem Grsnde } \\
\text { Ronde) }\end{array}$ & $\begin{array}{l}\text { Lostine } \\
\text { River" }\end{array}$ \\
\hline MEAN & 213.24 & 193.01 & 183.18 & 259.93 & 242.33 \\
\hline STDEV & 46.33 & 45.30 & 34.11 & 38.05 & 23.88 \\
\hline MAX & 292.10 & 293 & 255.00 & 298.00 & 284.00 \\
\hline MIN & 63.50 & 61.00 & 121.00 & 133.00 & 211.00 \\
\hline MODE & 254.00 & 220.00 & 185.00 & 270.00 & 231.00 \\
\hline COUNT & 348.001 & 184.001 & $\mathbf{4 . 3 . 0 0}$ & 29.00 & 12.04 \\
\hline
\end{tabular}

${ }^{*}$ The Lostine River trap began operations in November of 1996

\section{Fish captured $>\mathbf{3 0 0} \mathrm{mm}$ long.}

Generally, fluvial bull trout $>\mathbf{3 0 0} \mathrm{mm}$ long are considered to be sexually mature fish. These fish are not well represented in this data set probably due to a combination of rarity and trap avoidance. The 1993-96 Lookingglass Creek data set has the greatest number of observations with 1 in December, 6 in June, 4 in July, 4 in August and 4 in September. Fish captured September-December probably are downstream migrating spawners, fish captured June -August may be upstream migrating fish who were turned back by the weir at Lookingglass hatchery. The Lostine trap has the second largest catches with 7 fish ranging in size from 302-580 $\mathrm{mm}$ which were all caught in December of 1996. Since this trap had only been operating for 2 months it had the greatest catch per unit effort of bull trout $>300 \mathrm{~mm}$.

\section{Migration Timing}

Mean yearly catch rates by month and trap site are summarized in Table 4.3. The low catch rates of the lower Grande Ronde trap could reflect low overall trap efficiency in this wide river section. The only bull trout ever caught in this trap was a mortality believed to have been placed in the trap by vandals (Anne Setter, ODFW, personal communication). The Spoolcart trap also had low catch rates though there are six known populations of bull trout upstream of the trap. The majority of Elgin catches probably represent fish migrating down the mainstem Grande Ronde River. However, fish emigrating from Indian Creek, which joins the Grande Ronde River just upstream of the trap, may also be represented.

Bull trout catch per month, all years pooled for each data set for Lookingglass 1965-71, Lookingglass 1993-96, Catherine Creek, Elgin, Lostine and Lower Wallowa screw traps is illustrated in Figure 4.4.. Bull trout were caught throughout the year though there are definite peaks in catch rate in the spring and fall and a minimum in July. 
In Figure 4.5 Lookingglass 196571 and Lookingglass 1993-96 emigration data are plotted with mean stream flows from 1988-93. Timing of emigration does not appear to have changed. The spring emigration of smaller, younger fish appears to coincide with spring high flows. It appears that the spring emigration of bull trout through out the Grande Ronde Basin is associated with high spring flows.

Downstream migration patterns observed in the Grand Ronde River are composed of two components. There is a spring run occurring February through August and a fall run from September to January. These runs appear to be associated with flow and temperature conditions in the mainstem Grande Ronde River. Mean monthly trap catches and temperature and flow at Elgin, OR are plotted in Figure 4.6.

The spring run peaks April-May gradually declining to a minimum in July. This pattern mimics the flow regime of the Grande Ronde Basin. Migrating downstream at high flows enhances dispersion and is commonly observed in anadromous fish. The size distribution of bull trout caught during this period is mostly 2-3 year old fish. These facts lead us to conclude that this migration period is primarily composed of juvenile bull trout migrating into the Grande Ronde River from their rearing streams.

The second downstream migration period is from September to January. There is a small component of 2-3 year olds migrating from rearing areas to the Grande Ronde River during this period. The majority of fish captured during the fall downstream migration are 3-4 year old fish. These fish are probably returning to the Grande Ronde after migrating into tributaries to spawn or avoid high summertime water temperatures. In most studies of fluvial or adfluvial bull trout populations fish $>\mathbf{3 0 0} \mathrm{mm}$ long are not sexually mature (Pratt, 1992; USFS, 1989) except for precocious males. The fall emigration, composed mainly of fish $>200 \mathrm{~mm}$, probably older than 3 years, does not appear to be associated with any flow events. however, summertime water temperatures in the Grande Ronde River can exceed $27^{\circ} \mathrm{C}$ (Figure 4.7). Buchanan and Gregory (1997) note that bull trout are not found in temperatures in excess of $20^{\prime \prime} \mathrm{C}$. Unless thermal refugia exsist in the mainstem Grande Ronde River fish will be forced to emigrate to cooler tributaries during the summer months. The onset and increase of the fall run appear to be correlated with the cooler fall water temperatures. It can be seen in Figure 4.6 that as Grande Ronde temperatures decrease outmigration increases. Migration to tributaries by non-spawning fish to avoid high summertime water temperatures was also described Swanberg (1996) in the Upper Clark Fork River, Montana.

\section{Lookingglass Creek}

"Comparisons of historic and current bull trout emigrant data from Lookingglass Creek showed little difference in emigration timing, but significant differences in mean emigrant size. During the 196571 sampling period a greater 
proportion of February-August emigrants were $>\mathbf{2 0 0 m}$ long than during the 19931996 sampling period. This could represent either a larger percentage of the emigrants being 3+ year old fish or larger age two and three fish. Both the 65-71 and 93-96 data sets include a significant number of fish $>200 \mathrm{~mm}$ in the FebruaryAugust emigration period. At least some of these fish represent fish 3-4 year old. It is unknown if these fish are first time emigrants. Juvenile bull trout in most populations migrate downstream at 2-3 years old. The presence of these larger fish among downstream migrant catches suggests that some bull trout may remain in Lookingglass Creek for 4 years before migrating downstream. However they may also represent fish returning to the Grande Ronde River after migrating into Lookingglass Creek to overwinter.

The fall migration of bull trout in Lookingglass Creek resulted in captures of mostly $>200 \mathrm{~mm}$ long fish. In catches from the 1993-96 data set a greater proportion is represented by $100-200 \mathrm{~mm}$ fish than in the $1965^{\prime} 71$ data set. This suggests that now a larger proportion of fish are migrating from juvenile rearing areas in the fall than in 196571. Most of the larger bull trout captured are probably returning to the Grande Ronde River after moving up Lookingglass Creek to spawn or to escape high summertime water temperatures. Bull trout $>\mathbf{2 0 0} \mathbf{~ m m}$ in September- January may represent first time emigrant juveniles. It appears a greater proportion of 2-3 year old fish are emigrating to the Grande Ronde River in the fall in the 1993-I 996 data set than in the 1965-I 971 data set. 
Table 4.3. Comparison of mean monthly bull trout catch rates of fish traps operated in the Gra

\begin{tabular}{|c|c|c|c|c|c|c|c|c|}
\hline Month & $\begin{array}{c}\text { Lookingglass } \\
\text { Creek } \\
1965-71\end{array}$ & $\begin{array}{l}\text { Lookingglass } \\
\text { Creek } \\
\text { 1993-96 }\end{array}$ & $\begin{array}{c}\text { Catherine } \\
\text { Creek } \\
1993-96 \\
\end{array}$ & $\begin{array}{l}\text { Grande Ronde } \\
\text { atElgin } \\
1993-96 \\
\end{array}$ & $\begin{array}{l}\text { Spoolcart | } \\
\text { 1993-1996 }\end{array}$ & \begin{tabular}{l|} 
Ower Grande \\
Ronde River \\
19941996*
\end{tabular} & \begin{tabular}{|l|}
\multicolumn{2}{|c|}{ Wallowa } \\
River \\
1996 \\
\end{tabular} & $\begin{array}{l}\text { Los } \\
\text { Rive } \\
199 \\
\end{array}$ \\
\hline January & 1.83 & 1.33 & 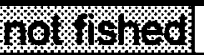 & 0.00 & nos gronos & 0 & . & \\
\hline February & 1.00 & 1.00 & mo V1 she & 0.00 & 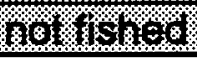 & 0 & ?. & (1) \\
\hline March & 3.67 & 3.33 & 350 & مم0م & $n-3$ & 0 & 1. & \\
\hline Anril & 3,00 & 4.67 & 4.50 & 1,00 & 0 & 0 & . & I: \\
\hline May & 4.83 & 5.00 & 3.00 & 0.33 & & 0 & . & ?. \\
\hline June & 1.83 & 6.00 & 1.00 & 0.50 & 0.7 & 0 & (3. & (.) \\
\hline July & 1.33 & 0.67 & 0.00 & 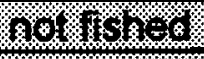 & 0 & 0 & . & (2. \\
\hline August & 1.00 & 2.33 & 6.00 & Mo:KS606 & 0 & 0 & 3 & . \\
\hline $\begin{array}{c}\text { Septemb } \\
-\mho_{I}\end{array}$ & 8.83 & 10.67 & 1.00 & not & 0 & 0 & \%. & : \\
\hline October & 16.50 & 12.33 & 4.00 & 0.00 & 0 & 0 & 姃. & 8 \\
\hline $\begin{array}{c}\text { Novembe } \\
r\end{array}$ & 3.83 & 5.33 & 1.33 & 2.00 & 0.3 & 0 & (4) & 9 \\
\hline $\begin{array}{c}\text { Decembe } \\
r\end{array}$ & 2.67 & 0.33 & 1702181800 & 1.00 & 9031101906 & 0 & 1 & 5 \\
\hline
\end{tabular}

${ }^{*}$ Only 1 bull trout was ever found in this trap, it was a mortality which was probably thrown intc unknown (A. Setter, personal communication, ODFW). 
Figure 4.4. Grande Ronde River juvenile $(>300 \mathrm{~mm})$ bull trout catches

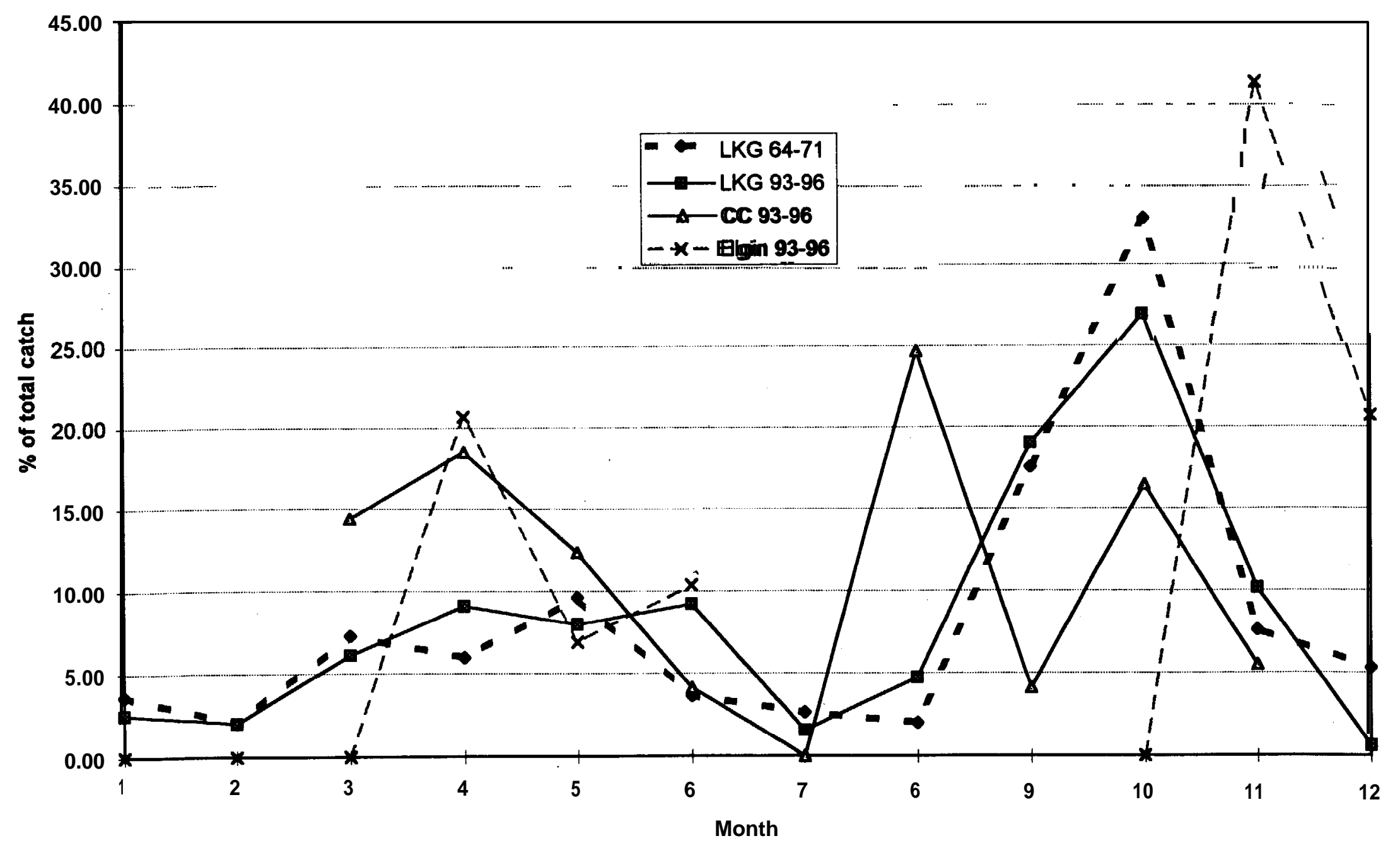


Figure 4.5. Lookinglass Creek downstream bull trout migrants and flows.

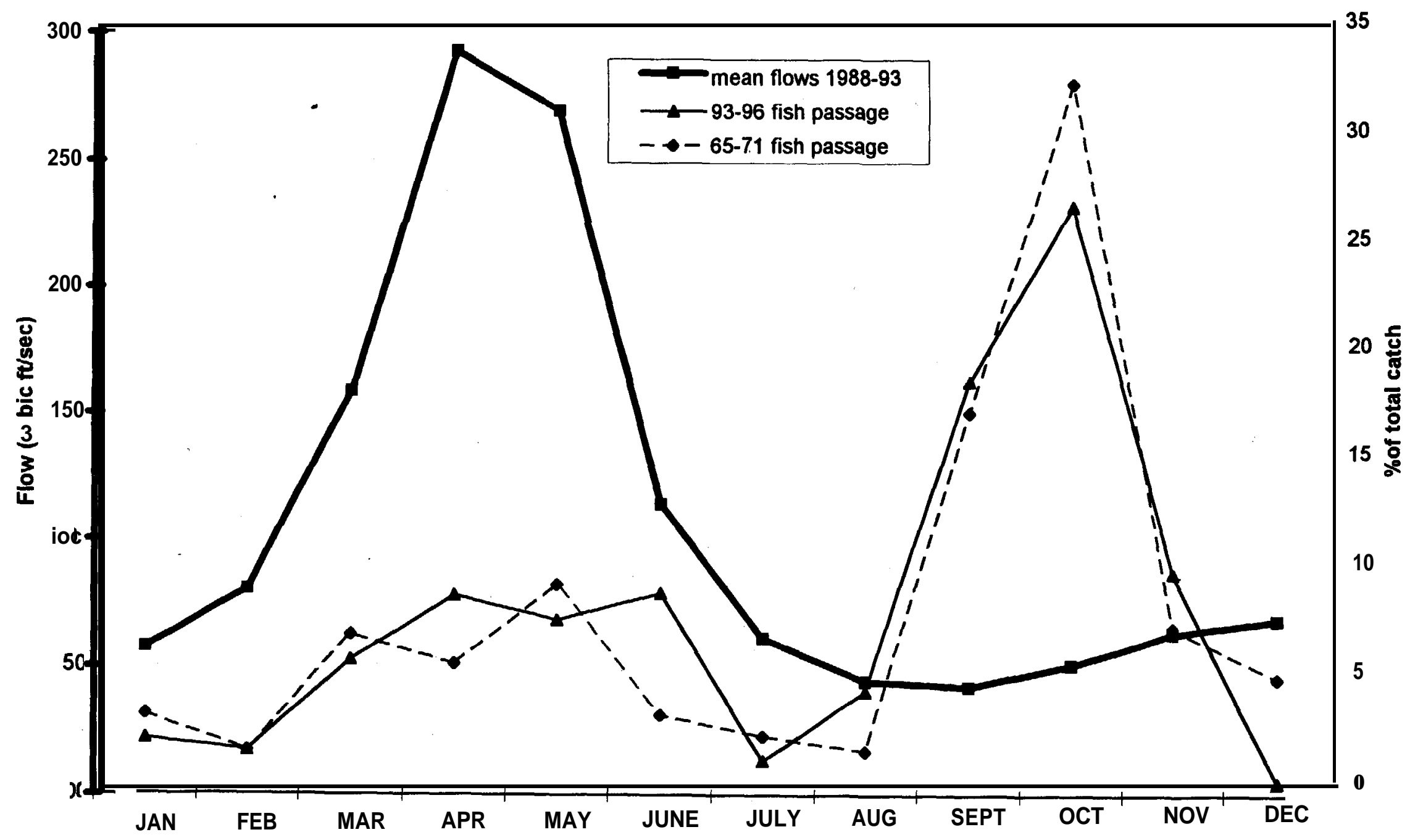

47 
Figure 4.6. Mean monthly bull trout catch plotted against mean monthly flows (196581) and temperature( 1994) of the Grande Ronde River at Elgin, OR.

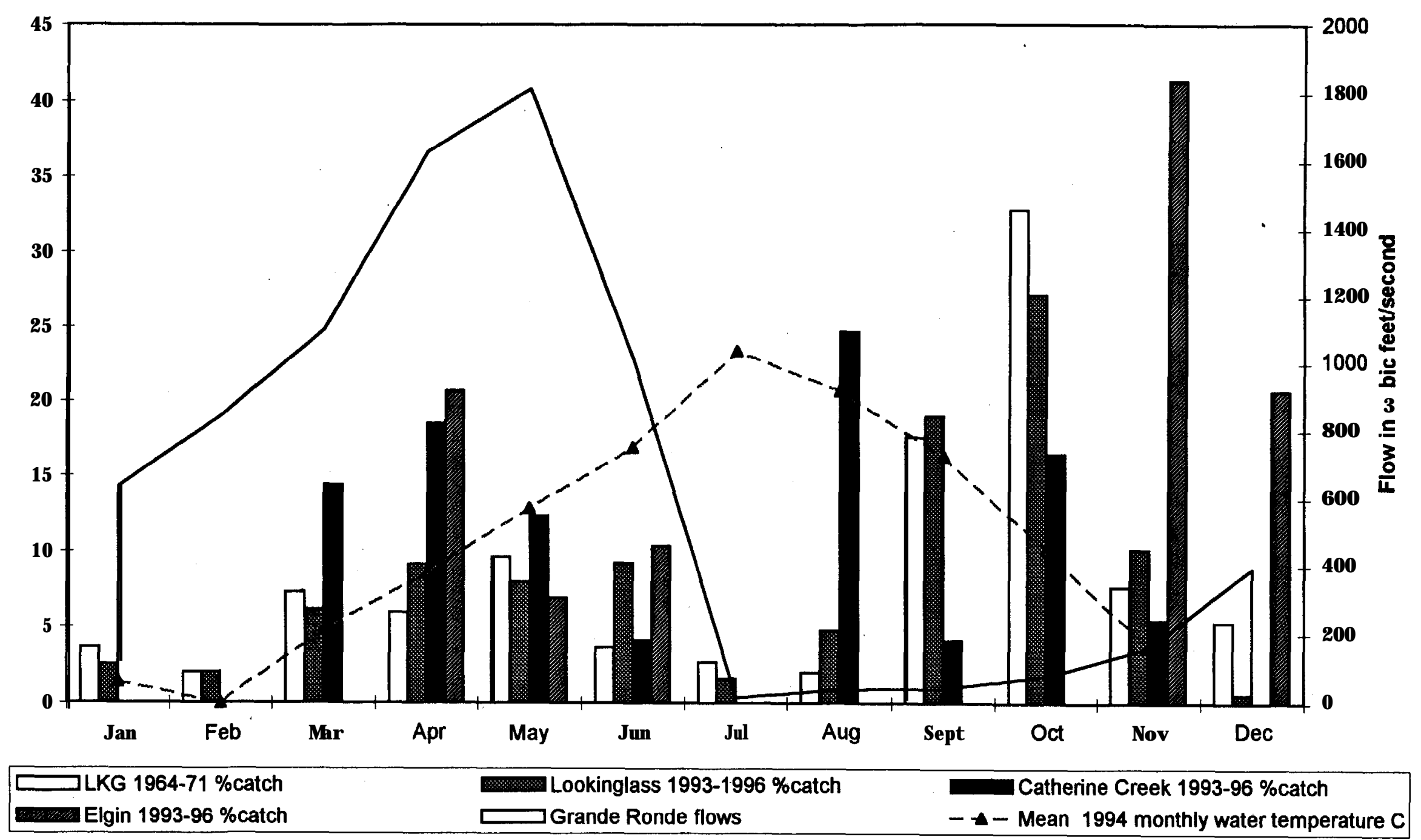


Figure 4.7 Grande Ronde River at Elgin, OR weekly mean, maximum and minimum water temperatures.

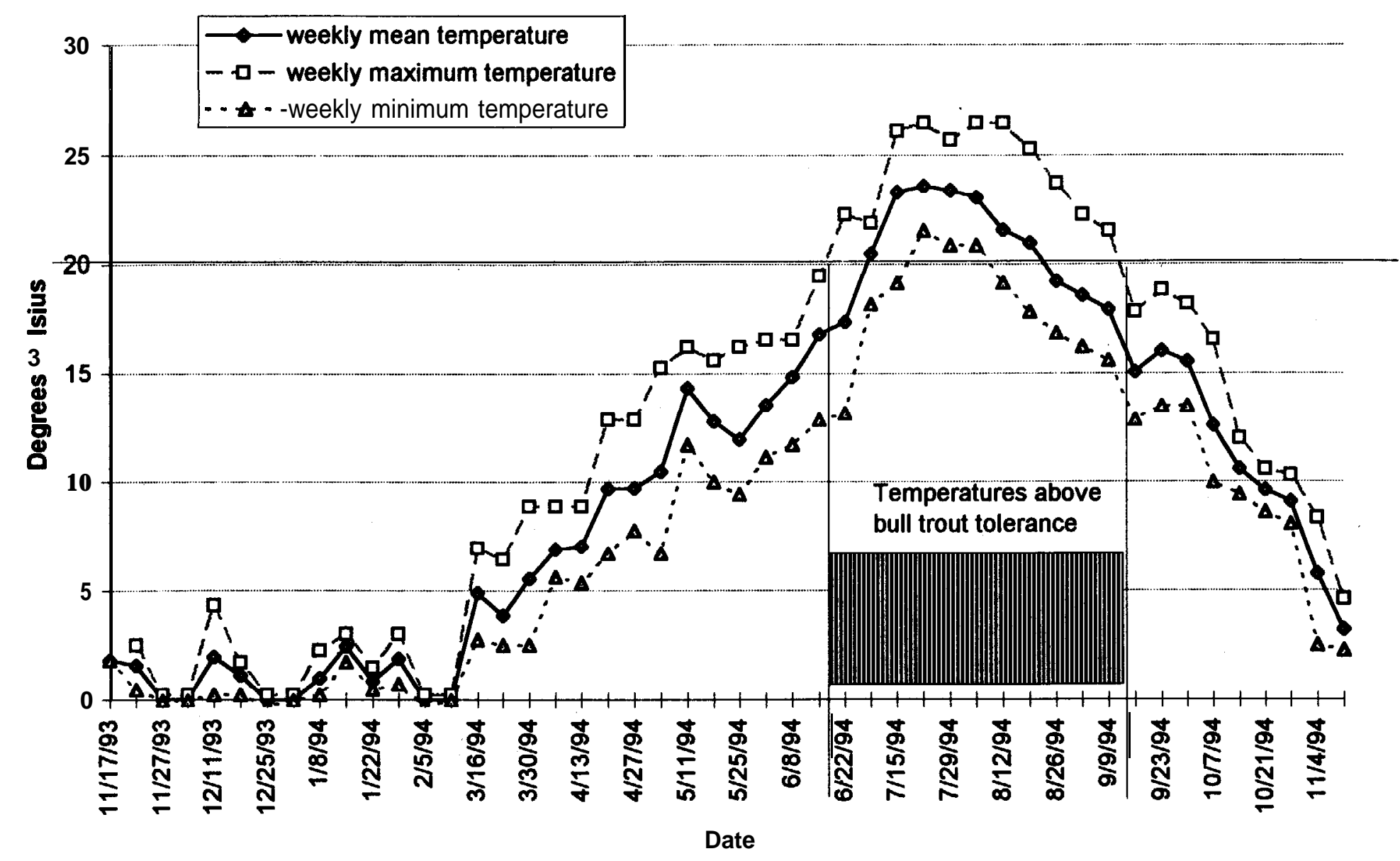




\title{
SECTION 5 \\ FOOD HABITS AND FEEDING BEHAVIOR OF BULL TROUT ALONE AND IN SYMPATRY \\ WITH BROOK TROUT
}

\author{
Introduction
}

In the summer of 1996 we undertook preliminary investigations to evaluate techniques and gather baseline information. This information will allow us to design a sampling strategy to better answer questions pertaining to the interactions of brook trout and bull trout.

\section{Methods}

\section{Description of Project Area}

The North Powder River drains the eastside of the Elkhorn Mountains, 56 kilometers west of Baker City, Oregon. The study site is the uppermost 4.8 kilometers miles of the headwaters. It is a steep, third order stream, with high gradient cascades. It is unusual for the number and size of large pools, the large volume of wood, and lack of human disturbance. The study site consists of three consecutive reaches each approximately one mile long. The top reach is allopatric for bull trout. The middle reach consists of bull trout and brook trout in sympatry. The final reach is allopatric for brook trout. The brook trout study reach is one mile long but the brook trout distribution extends downstream for an undetermined distance.

Meadow Fork of Big Creek is a third order tributary in the Malheur River Basin. It drains the south side of the Strawberry Mountains, 40 kilometers southeast of John Day, Oregon. The study site is seven miles long. The uppermost reach lies within the Strawberry Mountain Wilderness Area and is allopatric for bull trout. This reach is narrow with high gradient cascades. The middle reach contains bull trout, brook trout, and rainbow trout. It is located 2.4 40 kilometers downstream from the bull trout reach and consists of rapids and large channel-width pools. Large wood is abundant and provides complexity in the both upper reaches. The lowest reach, Big Creek, has brook trout, rainbow trout, and sculpin. This reach is low gradient, large volume, and has high grazing, and fishing pressure.

Sampling Procedures

To fully describe the feeding habits of bull trout and brook trout, an analysis of food availability is required. Prey availability was determined by describing the species composition of the benthic community and macroinvertebrate drift. Benthic macroinvertebrate samples were collected with a 
one square foot Surber sampler from six pools in each reach. Macroinvertebrate drift was collected from each study reach during the morning peak drift period with drift nets.

A minimum of ten individuals of each fish species present in each reach was captured by angling. The fish were anesthetized and stomach contents collected with non-lethal methods. Length, weight, and scales were also collected.

Three pools in each reach were selected for observation work. All fish present were observed for five minutes each. A time budget was calculated for each individual, measuring the time spent foraging, cruising, holding, and interacting with other individuals. The position, distance from substrate, and velocity at each feeding focal point was measured in addition to the physical characteristics of the pools.

\section{Results and Discussion}

Macroinvertebrate samples from 1996 are currently being analyzed. Analysis consists of identifying the macroinvertebrates in the benthic, drift, and invertebrate stomach samples to genus. A percent composition for each community will be derived and compared to the diet of the trout. From these results we will be able to identify diet preference for each trout species, potential resource partitioning between the trout species and a measure of diet overlap.

The objective of the observation work was to get baseline information to help design a tighter, more rigid sampling design to answer questions pertaining to the interaction of brook trout and bull trout. This goal was accomplished and the information is being used to develop a strategy to be conducted in 1997. 


\section{References}

Hemmingsen, A. R., D.V. Buchanan and P. J. Howell. 1995. Bull trout research work plan. Oregon Department of Fish and Wildlife. Corvallis, Oregon.

Buchanan, D. V, M. Hanson and B. Hooten. 1997. Bull trout status report for Oregon. Oregon Department of Fish and Wildlife. Portland, Oregon.

Buchanan, D.V. and S.V. Gregory. 1997. Development of water temperature standards to protect and restore habitat for bull trout and other coldwater species in Oregon. Proceedings of the Friends of the Bull Trout Conference.

Claire, E.W. and M.E. Gray. 1993. Bull trout report for John Day Fish District, Northeast Region. Oregon Department of Fish and Wildlife. Portland, Oregon.

Hemmingsen, A. R., D.V. Buchanan and P.J. Howell. 1996. Bull trout life history, Gentics, Habitat needs and limiting factors in central and northeast Oregon, 1995 Annual Report. Bonneville Power Administration. Portland, Oregon.

Hillman, T.W. and W.S. Platts. 1993. Survey plan to detect the presence of bull trout. Don Chapman Consultants Inc. Boise, Idaho.

James, P.W. and H.M. Sexauer. 1997. Spawning behavior, habitat and alternative mating strategies in an adfluvial population of bull trout. Friends of the Bull Trout Conference Preceedings. Calgary, Alberta.

Kitano, S., K. Maekawa, S. Nakano and K.D. Fausch. 1994. Spawning behavior of bull trout in the upper Flathead Drainage, Montana, with special reference to hybridization with brook trout. Transactions of the American Fisheries Society. 123:6 988-992.

Kustow, L. 1995. Biennial report on the status of wild fish in Oregon. Oregon Department of Fish and Wildlife. Portland, Oregon.

Leary, R.F., F.W. Allendorf and S.H. Forbes. 1993. Conservation genetics of bull trout in the Columbia and Klamath river drainages. Cons. Biol. 7:856-865

Pratt, K.L. 1992. A review of bull trout life history. Pages 5-9 in: P.J. Howell and D.V. Buchanan eds. Proceedings of the Gearhart Mountain bull trout workshop. Oregon Chapter American Fisheries Society, Corvallis, Oregon. Pages 5-9.

Rieman,B.E., J.D. Mclntyre. 1993. Demographic and habitat requirements for conservation of bull trout. U. S. Forest Service. Ogden, Utah. 
Markle, D.F. 1992. Evidence of bull trout $x$ brook trout hybrids in Oregon. Pages 58-67 in: P.J. Howell and D.V. Buchanan eds. Proceedings of the Gearhart Mountain bull trout workshop. Oregon Chapter American Fisheries Society, Corvallis, Oregon.

Martin, S.W. 1992. Southeast Washington Species interaction study: bull trout (Salvelinus confluentus), steelhead trout (Oncorhynchus mykiss) and spring chinook salmon (0. tshawytscha). Information Report 92-I. Bonniville Power Administration. Portland, Oregon.

Moore, K.M, K. Jones and J. Dambacher. 1996. Methods for stream habitat surveys version 6.1. Oregon Department of Fish and Wildlife, Research and Development section. Corvallis, Oregon.

Nakano, S. , S. Kitano, K. Maekawa, and K.D. Fausch. In Press. competitive interactions for foraging microhabitat among exotic brook trout (Salvelinus fontinalis), native bull trout (Salvelinus confluentus), and westslope cutthroat trout (Onchorhynchus clarki lewisi) in a Montana stream. Environmental Biology of Fishes.

Pratt, K.L. 1992. A review of bull trout life history. Pages 5-9 in: P.J. Howell and D.V. Buchanan eds. Proceedings of the Gearhart Mountain bull trout workshop. Oregon Chapter American Fisheries Society, Corvallis, Oregon.

Ratlif, D. E. 1992. Bull trout investigations in the Metolius River- Lake Billy Chinook System. Pages 37- 44 in: P.J. Howell and D.V. Buchanan eds. Proceedings of the Gearhart Mountain bull trout workshop. Oregon Chapter American Fisheries Society, Corvallis, Oregon.

Ratlifff, D.E. and P.J. Howell. 1992. The status of bull trout populations in Oregon. Pages 1 O-I 7 in: P. J. Howell and D.V. Buchanan eds. Proceedings of the Gearhart Mountain bull trout workshop. Oregon Chapter American Fisheries Society,

Spruell, P. and F.W. Allendorf. 1997 Nuclear DNA analysis of Oregon Bull Trout, Report 97/5. Oregon Department of Fish and Wildlife. Portland Oregon.

Swanberg, T. 1996. The movement and habitat use of fluvial bull trout in the upper Clark River drainage. M.S. Thesis. University of Montana.

Theisfield, S.L., A.M. Stuart, D.E. Ratliff and B.D. Lampman. 1996. Migration patterns of adult bull trout in the Metolius River and Lake Billy Chinook, Oregon. Oregon Department of Fish and Wildlife Information Report 96-I. Portland, Oregon. 
U.S. Forest Service 1989. Biology of the bull trout, Salvelinus confluentus, a literature review. Willamete National Forest. Eugene, Oregon.

Williams, R.N., R.P. Evans and D.K. Shiozawa. 1997. Mitochondrial DNA diversity in bull trout from the Columbia Basin. Proceedings of the Friends of the Bull Trout Conference. Calgary, Alberta. 


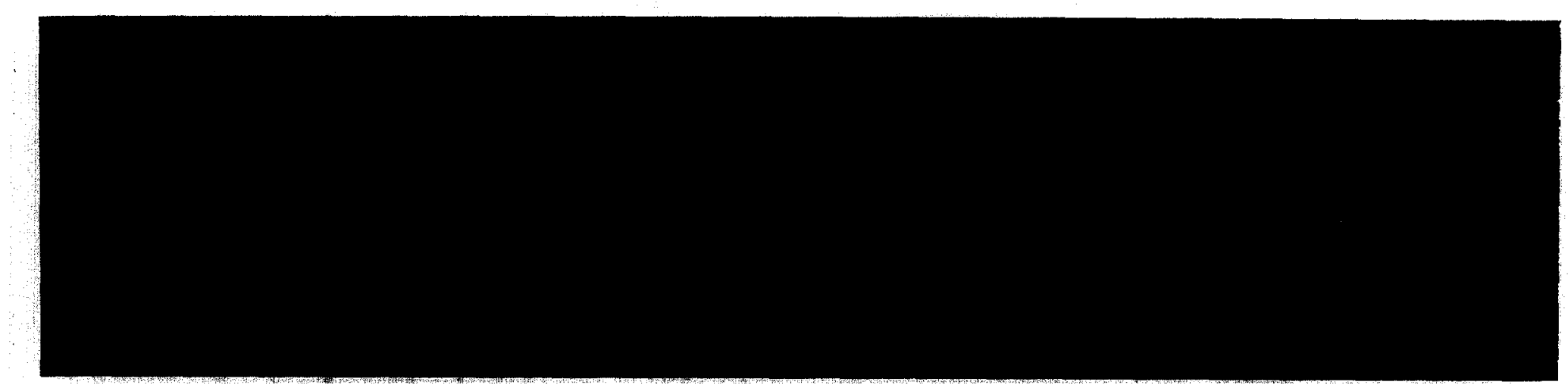

Bonneville Power Administration

PO Box 3621 Porlland, Oregon 97208-3621

DOE/BP-34342-2 JANUARY 1998613 